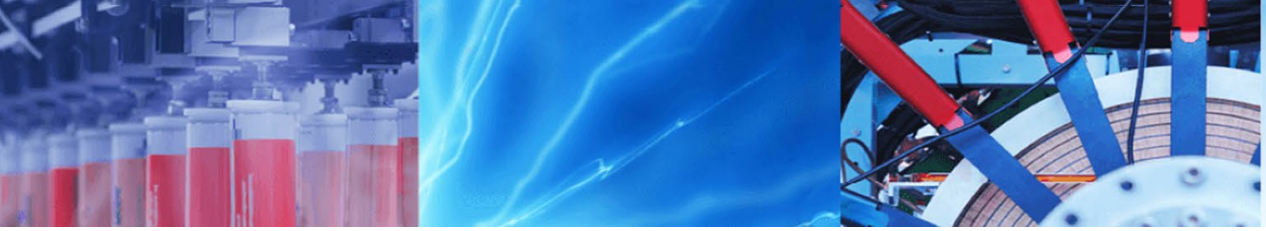

Review Paper

\title{
Recent developments and challenges ahead in carbon capture and sequestration technologies
}

\author{
Bheru Lal Salvi ${ }^{1}$ (D) Sudhakar Jindal ${ }^{1}$
}

(c) Springer Nature Switzerland AG 2019

\begin{abstract}
Rapid industrialization and increasing trend of energy utilization resulted into exploitation of natural resources, i.e., fossil fuels, for power generation. This is resulting into addition of huge amount of carbon dioxide $\left(\mathrm{CO}_{2}\right)$ as greenhouse gas into the environment. By year 2030, the primary production of energy from coal will reach to $3976 \mathrm{Mtoe}$ and $\mathrm{CO}_{2}$ discharge of $38749 \mathrm{MtCO}_{2}$ per year. In this review paper numerous aspects on carbon capture and sequestration (CCS) technologies have been compiled and discussed. The $\mathrm{CO}_{2}$ can be captured during fuel processing itself or after fuel combustion and transported to the sequestration site for long-term storage. A wide variety of the carbon separation and capture techniques including absorption into liquid, gas phase separation, and adsorption on solid and hybrid processes such as adsorption-membrane systems are discussed. In addition to this, the regulations for CCS, economic analysis and policy issues are addressed.
\end{abstract}

Keywords Clean energy $\cdot$ Carbon capture and sequestration $\cdot \mathrm{CO}_{2}$ mitigation $\cdot$ Hydrogen $\cdot$ Saline aquifer $\cdot$ Membrane separation

\section{Introduction}

Energy has been need of flourishing civilization, but utilization of conventional energy resources based on fossil fuels are creating environmental problems such as emissions of greenhouse gases, particulate matter, smoke, etc. About $82 \%$ of energy required all over in the world is generated from fossil fuels [1] through various modes. This is resulting into production of carbon dioxide $\left(\mathrm{CO}_{2}\right)$ and being released into the environment. The $\mathrm{CO}_{2}$ is a greenhouse gas (GHG) and primarily responsible for global warming as per [2].

Rapid industrialization and changing life style with increasing energy consumption pattern resulted into intense demand of power, which demanded into more electricity generation. On another side the growing fleet of automobiles in use resulted into more fuel consumption. Most of the power generation units (e.g., thermal power plants and diesel generator sets) and transportation vehicles (e.g., automobiles, trains, ships, aeroplanes, etc.) are based on fossil fuels. The combustion of fossil fuels (e.g., coal, diesel, gasoline and natural gas) produces lots of $\mathrm{CO}_{2}$, which is emitted into the environment. Apart from these chemical process and industries also produce $\mathrm{CO}_{2}$. Figure 1 , shows the world energy generation trend from different resources, where coal, oil and natural gas are the major sources of energy and their use is increasing continuously [2]. By year 2030, the primary production of energy from coal will reach to 3976 Mtoe and discharge of $\mathrm{CO}_{2}$ into environment about $38749 \mathrm{MtCO}_{2}$ per year.

The consumption of fossil fuels is resulting into $\mathrm{CO}_{2}$ discharge, where the electricity generation sectors are discharging highest $\mathrm{CO}_{2}$ followed by industries and transportation vehicles, as shown in Fig. 2 [2]. The concern over environmental protection resulted into start of $\mathrm{CO}_{2}$ sequestration, which is increasing with energy generation,

Bheru Lal Salvi, salvibl@yahoo.in | 'Department of Mechanical Engineering, College of Technology and Engineering, Maharana Pratap University of Agriculture and Technology, Udaipur, Rajasthan 313001, India.

SN Applied Sciences (2019) 1:885 | https://doi.org/10.1007/s42452-019-0909-2 


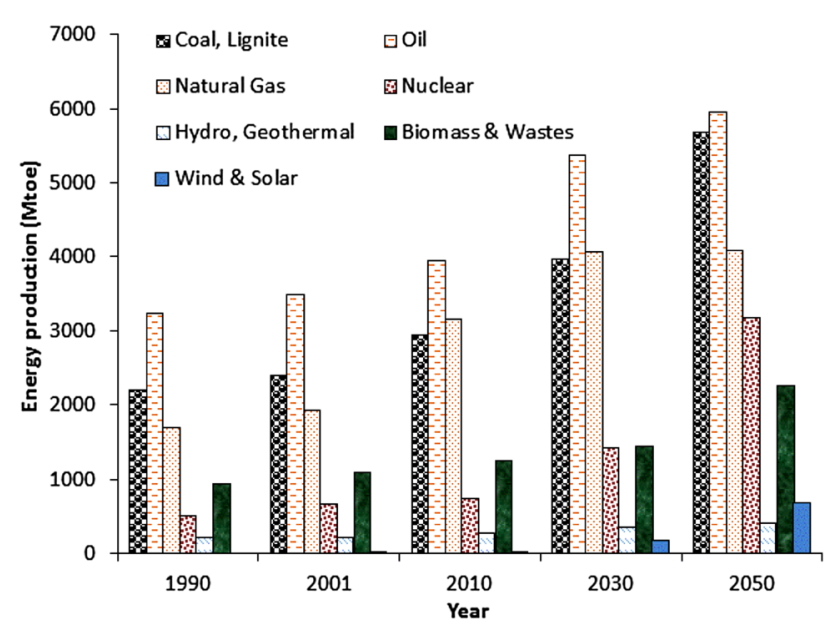

Fig. 1 World Energy generation from different resources (Data source: World Energy Technology Outlook-2050 [2])

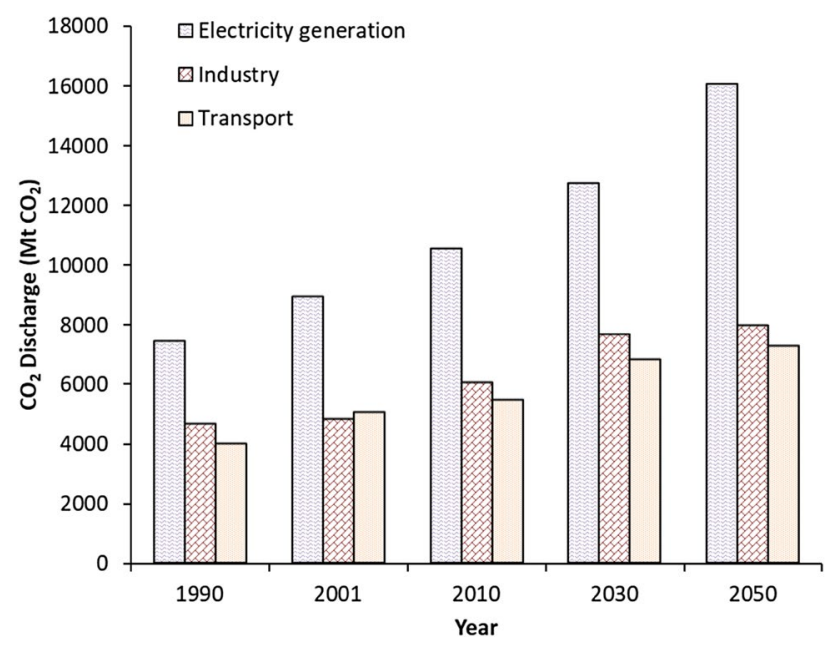

Fig. 2 Carbon dioxide discharge from various sectors (Data source: World Energy Technology Outlook-2050, 2006 [2])

as shown in Fig. 3 [2]. By year 2050, fossil fuels and petroleum consumption will be dominating in the market, leading to more environmental pollution. During power generation the direct combustion of hydrocarbon based fuels, i.e., fossil fuels, in heat engines (i.e., external combustion and internal combustion engines) produce exhaust emissions such as $\mathrm{NO}_{x^{\prime}} \mathrm{CO}, \mathrm{HC}, \mathrm{SO}_{x^{\prime}} \mathrm{PM}$, smoke and soot as well as $\mathrm{CO}_{2}$ as unregulated emission, as shown in Fig. 4.

Long back, a theory of life expectancy for the Industrial Civilization was proposed by Olduvai, which reported the expected life of industrial civilization between the years 1930-2030 [4]. After discovery of fossil fuels, the human civilization entered into the Industrial Civilization and the energy generation per capita increased. Muda and Pin [5] carried out a numerical study on depreciation time of fossil

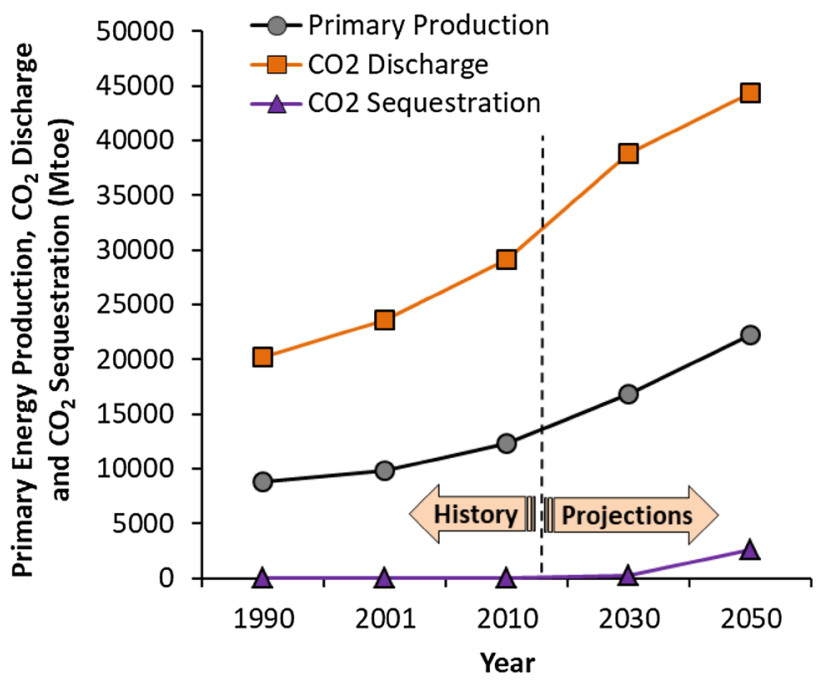

Fig. 3 Energy generation, $\mathrm{CO}_{2}$ emissions and sequestration (Data source: World Energy Technology Outlook-2050 [2])

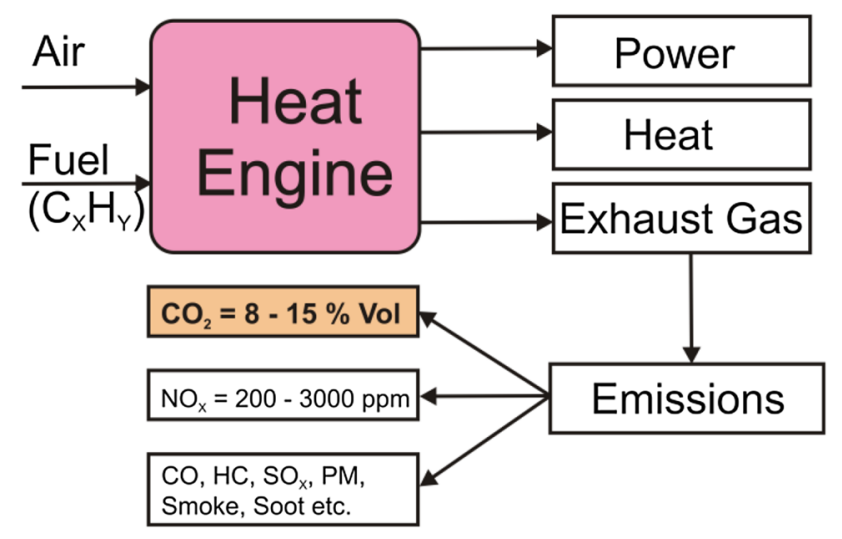

Fig. 4 Power generation using hydrocarbon fuels and pollutants emission (Source: Salvi and Subramanian [3])

fuels and reported that petroleum will deplete faster due to its massive consumption and subsequently the natural gas and coal will be major sources of energy. In United States, the power plants for electricity generation alone contributes over $40 \%$ of U.S. $\mathrm{CO}_{2}$ emissions from fossil fuels [6].

The fossil fuel based energy generation is resulting into huge amount of $\mathrm{CO}_{2}$ discharge into the environment. Thus, increasing demand of energy is leading to greater concentration of GHG into the atmosphere and creating a threat to the very existence of civilization on the globe. Therefore, it is need of time to reduce $\mathrm{CO}_{2}$ generation and addition into the environment.

This review work is aimed for thorough compilation of literature for generation of clean energy and $\mathrm{CO}_{2}$ mitigation with carbon capture and sequestration (CCS) 
technologies. Different methods of carbon separation and capture techniques including absorption into liquid, gas phase separation, adsorption on solid and hybrid processes such as adsorption-membrane systems are discussed. In addition to this, the regulations for CCS, economic analysis and policy issues are addressed.

\section{Clean energy generation}

Growing need of energy is leading to more consumption of fossil fuels, which is resulting into further addition of anthropogenic emissions, especially $\mathrm{CO}_{2}$ emission, to the environment. Instead of direct use of fossil fuels, it can be processed to produce the hydrogen along with carbon capture and storage of captured carbon at suitable storage site.

The energy generation from hydrogen fuel is one of the suitable options, as utilization of hydrogen energy is $\mathrm{CO}_{2}$ free. Hydrogen has many unmatched properties including higher flammability limit (4-75) \% by volume, lower ignition energy $(0.02 \mathrm{~mJ})$, low density $\left(0.083 \mathrm{~kg} / \mathrm{m}^{3}\right)$ at NTP $[3,7]$ and no carbon contents as compared to the conventional fuels, like gasoline, methane, biogas, etc. The National Hydrogen Energy Board of India has prepared the hydrogen road map of India and targeted about one million hydrogen fuelled vehicles on Indian roads by year 2020. It was aimed to develop a useful bridge for future pure-hydrogen and fuel cell vehicles, particularly through the cost effective introduction of a hydrogen infrastructure [8]. The hydrogen supply for short term and immediate needs can be accomplished by steam reforming, partial oxidation of heavy hydrocarbons and gasification or partial oxidation of coal. The hydrogen can be produced from primary sources of energy (e.g., coal, natural gas and biomass) as well as renewable energy sources (e.g., solar, hydro and wind power). For the immediate supply and mid-term supply, it can be produced from the primary energy sources such as fossil fuels, i.e., Natural gas, Coal, etc. [7, 9]. Wang and Cao [10] carried out a combined theoretical and experimental study for generation of hydrogen and reported that $\mathrm{NiO}$ could convert $\mathrm{C}_{2} \mathrm{H}_{5} \mathrm{OH}$ to $\mathrm{H}_{2}, \mathrm{CO}$, $\mathrm{CO}_{2} \mathrm{CH}_{4}$ and $\mathrm{H}_{2} \mathrm{O}$ almost completely. The hydrogen concentration increases with increasing $\mathrm{NiO} / \mathrm{C}_{2} \mathrm{H}_{5} \mathrm{OH}$ molar ratio in the range from 1 to 3 at temperatures below $800 \mathrm{~K}$.

The major challenge in moving towards a futuristic hydrogen energy system is the production of sufficient quantity of hydrogen in an efficient and environmentally benevolent manner. The production of hydrogen through all above methods, by using carbon fuels, produces the $\mathrm{CO}_{2}$ as by-product. Thus, generated $\mathrm{CO}_{2}$ has to be captured and sequestered, so that the total process becomes nearly clean from $\mathrm{CO}_{2}$ emission into the environment. In order to avoid the economic and human consequences of severe climate change, the $\mathrm{CO}_{2}$ emission must significantly be reduced. Any approach to develop eco-friendly energy system will inevitably involve certain methods including improvement in energy efficiency, reduction of $\mathrm{CO}_{2}$ emissions, and substitution of high carbon-emitting fuels with low carbon fuels, such as gas, etc. As long as fossil fuels (i.e., gas, oil and coal) continue to provide utmost of the world's total energy; there is a need to capture and sequester the $\mathrm{CO}_{2}$. A pathway for sustainable energy supply system is shown in Fig. 5. Variety of feed-stocks including fossil coal, natural gas and biomass can be used for clean hydrogen production with $\mathrm{CO}_{2}$ capture technology. The produced hydrogen can be used as fuel for existing transportation systems with small modification and in fuel cells for electricity generation.

\section{Carbon capturing and sequestration}

Carbon capture and sequestration, known as CCS, is one of the technological steps toward the clean energy generation. Any technique that prevent or reverse the release of $\mathrm{CO}_{2}$ into the atmosphere and divert the carbon to a viable carbon sink can be considered as carbon capture and sequestration (CCS). The CCS refers to process of capturing $\mathrm{CO}_{2}$ at its source and storing it before its release to the atmosphere. The worldwide efforts on CCS were started in March 1992 at Amsterdam where many scientists and engineers from various countries gathered in the First International Conference and discussed about Carbon Dioxide Removal. It is established that the clean energy can be produced by either removal of carbon from the fuel itself or removal from post-combustion exhaust gases [3]. The CCS methodology can reduce or even eliminate the

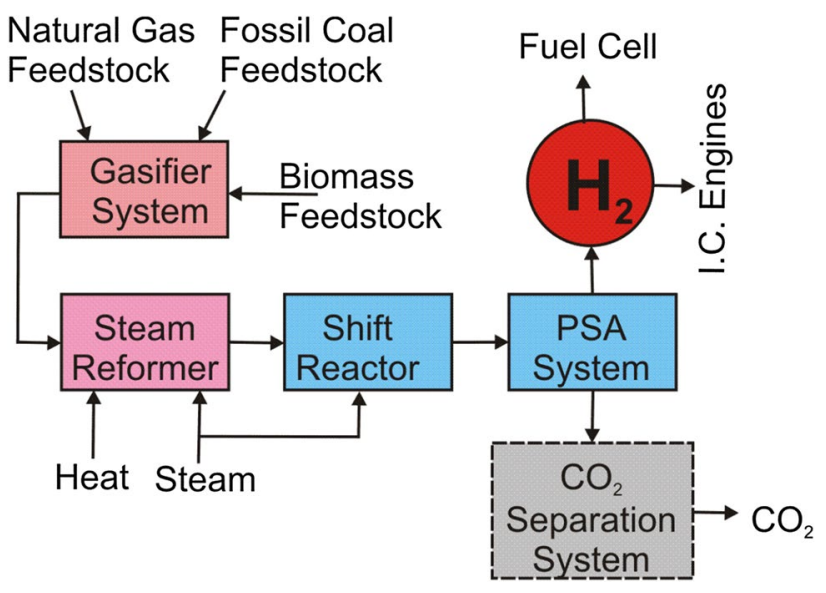

Fig. 5 A pathway for sustainable energy supply system (Source: Salvi and Subramanian [3]) 
$\mathrm{CO}_{2}$ emission to the atmosphere and clean energy can be produced [9] and it may be a long-term solution to curb carbon emissions [11]. Taiwan has recognized that before arrival of new energy era, the carbon capture and storage (CCS) technologies are to be practiced to permit the continuing use of fossil fuels for energy security and economic development while reducing the emission of $\mathrm{CO}_{2}$ into the atmosphere [12]. In Nigeria, also attention is being given on CCS activities for continuing utilization of fossil fuels for power generation [13]. The CCS is mid-term solution for utilization of fossil fuels and adoption to use of renewable sources of energy for long term sustainability [14].

The amounts of $\mathrm{CO}_{2}$ generation and addition in environment are very large. Typically, a coal-fired power plant with a capacity of 1000 MWe generates approximately 30,000 tonnes of $\mathrm{CO}_{2}$ per day $[15,16]$. The $\mathrm{CO}_{2}$ released by power plants can be mitigated by CCS techniques, but the cost is quit high [17]. An integrated CCS system will include the three main steps: (1) Capturing and separating the $\mathrm{CO}_{2}$, (2) Compression and transportation of the captured $\mathrm{CO}_{2}$ to the sequestration site and (3) sequestration of $\mathrm{CO}_{2}$ in geological reservoirs or the oceans. The main options for sequestration include (a) use of deep saline reservoirs, (b) injection of $\mathrm{CO}_{2}$ into hydrocarbon deposits to enhance oil recovery (EOR) or production of coal-bed methane (CBM), and (c) injection into the deep ocean [7]. The deep saline formations (100-1000 GtC) and Oceans $(1000 \mathrm{GtC})$ are having highest world sink capabilities of $\mathrm{CO}_{2}$ disposal options [10].

The CCS can be implemented in two ways: (1) precombustion CCS process, where carbon is captured during fuel processing itself, before combustion of fuel for generation of energy and (2) post-combustion CCS process, where separation of $\mathrm{CO}_{2}$ from combustion products, i.e., flue gases, is done after combustion of the fuel. Removing $\mathrm{CO}_{2}$ from the atmosphere by enhancing its uptake in soils and vegetation (e.g., afforestation) or in the ocean (e.g. iron fertilization) is yet another form of sequestration.

\subsection{Pre-combustion CCS}

In pre-combustion CCS process, the fuel (generally coal, crude oil or natural gas) is pre-treated before combustion. In case of coal, the pre-treatment involves a gasification of coal in a gasifier under low oxygen level forming a syngas, which consists mainly of $\mathrm{CO}$ and $\mathrm{H}_{2}$, as shown by Eq. (1). The syngas then undergo water-gas shift reaction with steam forming more $\mathrm{H}_{2}$ while the $\mathrm{CO}$ gas will be converted to $\mathrm{CO}_{2}$, as shown in Eq. (2). The steam-methane reforming also produces $\mathrm{CO}$ and then $\mathrm{CO}_{2}$, as shown in Eq. (3).

$$
\text { Coal } \stackrel{\text { Gasification }}{\longrightarrow} \mathrm{CO}+\mathrm{H}_{2}
$$

$\mathrm{CO}+\mathrm{H}_{2} \mathrm{O} \stackrel{\text { Water-gas shift }}{\longrightarrow} \mathrm{H}_{2}+\mathrm{CO}_{2}$

$\mathrm{CH}_{4}+\mathrm{H}_{2} \mathrm{O} \stackrel{\text { Reform }}{\longrightarrow} \mathrm{CO}+\mathrm{H}_{2}$

The high concentration of $\mathrm{CO}_{2}$ in the $\mathrm{H}_{2} / \mathrm{CO}_{2}$ fuel gas mixture necessitates the $\mathrm{CO}_{2}$ separation [10]. Subsequent burning of $\mathrm{H}_{2}$ in air produces mainly products of $\mathrm{N}_{2}$ and water vapour, eliminating the $\mathrm{CO}_{2}$ emission to the atmosphere.

\subsection{Post-combustion CCS}

The capturing and sequestration of $\mathrm{CO}_{2}$ from the flue gases, before being emitted into the atmosphere is termed as post-combustion CCS. The post-combustion technologies are preferred options for retrofitting the existing power plants [18]. The post-combustion CCS technology has been proven at small-scale; however, the major challenges in it are its large parasitic load because of low concentration of $\mathrm{CO}_{2}$ in combustion flue gas and related costs for the capture unit to increase the concentration of $\mathrm{CO}_{2}$ (above 95.5\%) needed for transport and storage. The postcombustion approaches in use today require clean-up of products of $\mathrm{N}_{2}, \mathrm{NOx}$ and $\mathrm{SO}_{2}$ before $\mathrm{CO}_{2}$ separation [19].

\section{Development of CCS technologies for $\mathrm{CO}_{2}$ capture}

The emerging technologies comprise a combination of products and processes that have demonstrated, either in the laboratory or in the field, significant improvements in efficiency and cost over the current level of knowledge and development achieved in technologies. There are numerous methods for $\mathrm{CO}_{2}$ separation and capture including absorption, adsorption, cryogenics, membrane separation and microbial/algal system $[18,20]$, as shown in Fig. 6. The emerging technologies involved in carbon capture range from major improvements in existing processes to highly novel approaches.

\subsection{Membrane separation process}

The membrane separation process contains a specially designed membrane sieve that separates molecules based on their molecular size. Several demonstrations of $\mathrm{CO}_{2}$ separation have been performed, notably the separation of $\mathrm{CO}_{2}$ from $\mathrm{CH}_{4}, \mathrm{CO}_{2}$ from air and $\mathrm{CO}_{2}, \mathrm{CO}, \mathrm{H}_{2} \mathrm{~S}$ and $\mathrm{H}_{2} \mathrm{O}$ from a mixture of gases [21,22]. Use of membranes for removing $\mathrm{CO}_{2}$ provides versatility, adaptability, environmentally 
Fig. 6 Technical options for $\mathrm{CO}_{2}$ separation and capture (Prepared by authors based on information from sources: Rubin et al. [18], Rao and Rubin [20])

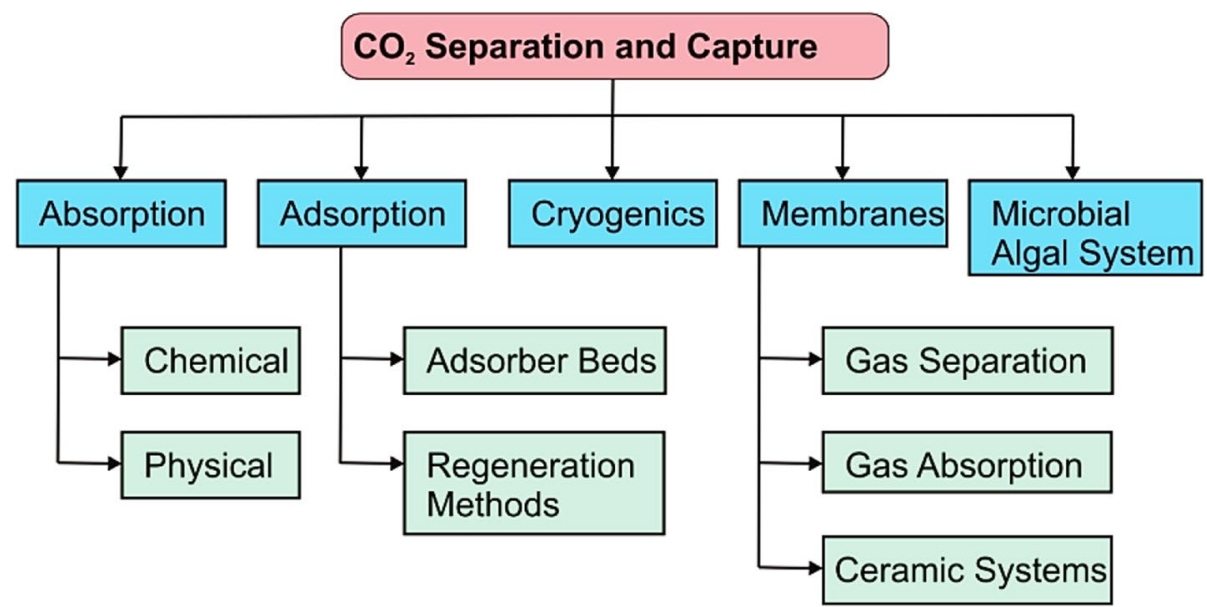

friendly, easy to operate, requires less space and light in weight.

Membranes in application are polymeric gas permeation membranes (PGPM), facilitated transport membranes (FTM), hollow fibre gas-liquid membrane contactors, inorganic membranes and mixed matrix membranes (MMM). Low manufacturing cost of polymeric membranes is of great interest for industrial applications, but they generally exhibit selectivity about 5-10 fold lower than those of inorganic membranes. The inorganic membranes are useful for $\mathrm{CO}_{2}$ separation processes at high temperatures due to their robust thermal, chemical and mechanical stability; however, more $R \& D$ is required to improve the reproducibility, reliability and to reduce cost [22]. Polymer membranes with better plasticization suppression properties are useful for $\mathrm{CO}_{2}$ separation, but aging and conditioning of polymer membranes need to be investigated [21]. Hasebe et al. [23] fabricated high gas permeable separation membranes containing silica nano-particles, a type of MMM. They reported that gas transport channel formed by the nano-particles can enhance the gas permeability without significant decrease in gas selectivity and the syntheses of silica nano-particles are cost-effective.

A two-stage membrane based process with boiler air feed as a sweep stream to increase the $\mathrm{CO}_{2}$ concentration for $\mathrm{CO}_{2}$ capture was studied and optimised by Mat and Lipscomb [24]. They reported slightly higher operating pressure, but achieved the target for less than a $35 \%$ increase in electricity cost for $\mathrm{CO}_{2}$ capture. However, boiler air feed sweep stream leads to a detrimental reduction in the $\mathrm{O}_{2}$ concentration of the feed air to the boiler [24]. With use of the facilitated transport membrane the $\mathrm{CO}_{2}$ separation is feasible, even for low $\mathrm{CO}_{2}$ concentration about $10 \%$ in flue gas and it is possible to achieve more than $90 \% \mathrm{CO}_{2}$ recovery and with a purity in the permeate above $90 \% \mathrm{CO}_{2}$ [25].

The membrane-based technologies are under development targeting for advancement towards sustainable systems that minimizes $\mathrm{CO}_{2}$ emissions. Research work is on the way for membrane separation technologies including non-dispersive absorption using porous membranes, gas permeation and supported liquid membranes [26]. With currently available membranes having selectivity up to 50 , it is difficult to get simultaneously, desired $\mathrm{CO}_{2}$ recovery and purity $\left(80 \% \mathrm{CO}_{2}\right.$ in permeate stream) [27]. The arguments in favour of membrane separation technology are that it is cost effective (once developed on a commercial level), produce minimal waste and can be adapted to a variety of carbon sequestration schemes.

\subsection{Adsorbent based systems}

An adsorbent is a substance, usually porous in nature and with high surface area that can adsorb substances onto its surface by intermolecular forces. It is capable of holding other molecules on its surface by physical or chemical means. The adsorbate is the substance, which is adsorbed on the surface. The adsorbent beds are regenerated, i.e., release of adsorbate, by pressure swing, temperature swing and washing methods [18]. The solid adsorbents are classified into amine-based and alkali (earth) metal-based adsorbent. The various adsorbents with adsorption environment and $\mathrm{CO}_{2}$ capturing capacity are shown in Table 1 [28].

The carbonate systems are based on the ability of a soluble carbonate to react with $\mathrm{CO}_{2}$ to form a bi-carbonate, which when heated releases $\mathrm{CO}_{2}$ and reverts to a carbonate. In a research it was reported that $\mathrm{K}_{2} \mathrm{CO}_{3}$ based system with catalyst of pipe razine (PZ), the $\mathrm{K}_{2} \mathrm{CO}_{3} / \mathrm{PZ}$ system (5 molar K; 2.5 molar PZ) has shown an absorption rate $10-30 \%$ faster than a $30 \%$ solution of mono-ethanolamine (MEA) $[29,30]$. The mineral carbon sequestration has the potential to capture and store $\mathrm{CO}_{2}$ in a single step. Bobicki et al. [31] carried out an overview of the types of industrial wastes that can be used for mineral carbon sequestration 
Table 1 Solid adsorbents with environmental requirement and functionality [28]

\begin{tabular}{|c|c|c|c|}
\hline Adsorbent & Examples & Adsorption environmental condition & $\begin{array}{l}\mathrm{CO}_{2} \text { capturing } \\
\text { capacity up to } \\
(\mathrm{mmol} / \mathrm{g})\end{array}$ \\
\hline Amine-based solid sorbent & $\begin{array}{l}\text { silica gels, activated carbon, } \\
\text { tetraethylene pentamine }\end{array}$ & $\begin{array}{l}\text { At }-20^{\circ} \mathrm{C} \text { to } 75^{\circ} \mathrm{C} \text { in absence of water } \\
\text { vapour and pressure } 1 \text { bar }\end{array}$ & 4.3 \\
\hline Alkali earth metal-based solid sorbents & $\mathrm{CaO}, \mathrm{MgO} / \mathrm{ZrO}_{2}, \mathrm{MgO} / \mathrm{Al}_{2} \mathrm{O}_{3}$ & $\begin{array}{l}\text { Absence of water vapour and high tem- } \\
\text { perature between } 600^{\circ} \mathrm{C} \text { and } 650^{\circ} \mathrm{C}\end{array}$ & 1.39 \\
\hline Alkali metal carbonate solid sorbents & $\begin{array}{l}\mathrm{Na}_{2} \mathrm{CO}_{3} \text { and } \mathrm{K}_{2} \mathrm{CO}_{3}, \mathrm{MgO}, \mathrm{ZrO}_{2} \\
\mathrm{SiO}_{2}, \mathrm{Al}_{2} \mathrm{O}_{3}, \mathrm{TiO}_{2}, \mathrm{CaO} \text {, and } \\
\text { zeolites }\end{array}$ & Low temperatures with water vapour & 2.49 \\
\hline
\end{tabular}

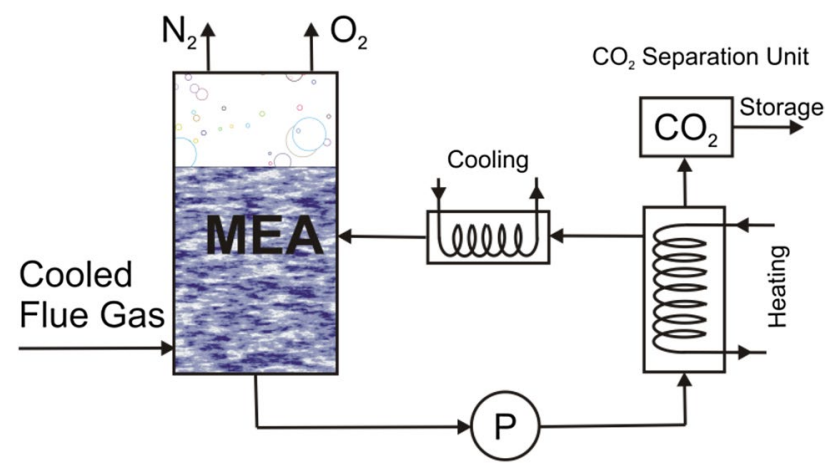

Fig. 7 Mono-ethanolamine scrubbing process (prepared by Authors based on information from sources: Figueroa et al. [34], Veawab et al. [35], Leung et al. [36])

and the process routes available. The varieties of industrial wastes are difficult to be converted from one to another, and each waste has its own unique characteristics. The abandon wastes generated from cement contain a large fraction of $\mathrm{CaO}$, which can be used as $\mathrm{CO}_{2}$ adsorbent. In a review of the underground coal gasification (UCG) technologies, it was reported that UCG is a suitable technique for production of low carbon fuel by capturing $\mathrm{CO}_{2}$ generated at gasification site itself $[32,33]$.

\subsection{Amine based scrubbing process}

Amine based systems are able to recover $\mathrm{CO}_{2}$ from flue gases as the amine react with $\mathrm{CO}_{2}$ to form water soluble compounds [34]. In mono-ethanolamine scrubbing process, a chemical absorption process is used with a monoethanolamine (MEA) solvent whereby $\mathrm{CO}_{2}$ is scrubbed from the flue gases of the combustion process. The process allows the MEA solution to come into contact with the flue gases and mix in the absorber. The absorption takes place at temperatures around $38^{\circ} \mathrm{C}$. The $\mathrm{CO}_{2}$ rich MEA solution is then passed to a stripper, where it is reheated to a temperature of $150{ }^{\circ} \mathrm{C}$ to release almost pure $\mathrm{CO}_{2}$. The MEA solution is then recycled to the absorber, as shown in Fig. 7.
Other amine compounds such as di-glycolamine (DGA), di-ethanol amine (DEA), tri-ethanol amine (TEA) and methyl diethanol amine (MDEA) can also be used for scrubbing, but the MEA is the most efficient for $\mathrm{CO}_{2}$ absorption with efficiency over $90 \%[35,36]$. The separated $\mathrm{CO}_{2}$ can be utilized for any industrial application or can be sequestrated. This process is generally deemed uneconomical as it results in large equipment sizes and high regeneration energy requirements (about $30 \%$ of the energy produced) to release the $\mathrm{CO}_{2}$ from MEA. The regeneration heat energy may be received from the solar heating system. Apart from this, the additives can help to improve the system performance and the design modifications are possible to drop capital costs and increase energy integration (Figueroa et al., 2008) [34]. The carbon capture through solvent process should be oriented to produce $\mathrm{CO}_{2}$-based products with economic value that can be reintegrated in a closed carbon loop, which will reduce the use of fresh materials and decreasing the production cost [37].

The energy consumption required to regenerate the solvent can be reduced by using ejector technology into post-combustion carbon capture. A numerical simulation study was targeted for $85 \%$ capture rate for the simulated $400 \mathrm{MW}$ coal-fired power plant flue gases, using $20 \%$ wt MEA as the reference solvent. There was valuable energy savings of $14 \%$ and $23 \%$ when the ejector secondary steam was produced from the stripping column condensate and the lean solvent, respectively [38], while in similar study the energy savings of $10 \%$ and $14 \%$ was reported by Reddick et al. [39].

In order to overcome the limitations of energy intensive process MEA scrubbing, another technique called reactive hydrothermal liquid phase densification (rHLPD), is used to solidify monolithic material without using high temperature kilns. The integration of MEA based CCS processing and mineral carbonation by using rHLPD technology results into formation of a mineral (wollastonite $\mathrm{CaSiO}_{3}$ ), which has high compressive strength of $\sim 121 \mathrm{MPa}$. The produced material, similar to Portland cement, can be 
used as value added binding material for construction and infrastructure development [40]. Mineral carbonation is an alternative method for CCS where value added product is produced [41].

\subsection{Aqueous ammonia scrubbing of $\mathrm{CO}_{2}$}

The ammonia-based carbon capture technology can be divided into the normal temperature method $\left(15-30^{\circ} \mathrm{C}\right)$ and the low temperature method $\left(2-10^{\circ} \mathrm{C}\right)$. In ammoniabased wet scrubbing of $\mathrm{CO}_{2}$, the flue gas is passed through aqueous ammonia. The ammonia and its derivatives react with $\mathrm{CO}_{2}$ via various mechanisms, one of which is the reaction of ammonium bicarbonate. In this mechanism the lower heat of reaction for amine-based systems, results in energy savings. Aqueous ammonia scrubbing of $\mathrm{CO}_{2}$ and ammonium bicarbonate production process is shown in Fig. 8. The ammonia-based absorption has a number of other advantages such as the potential for high $\mathrm{CO}_{2}$ capacity, lack of degradation during absorption/regeneration, tolerance to oxygen in the flue gas and low cost [34]. Based on thermodynamic analysis and process simulation it was found that the equilibrium regeneration energy can be reduced to $1285 \mathrm{~kJ} / \mathrm{kg} \mathrm{CO}_{2}$ and the energy consumption for the $\mathrm{NH}_{3}$ abatement system is $1703 \mathrm{~kJ} / \mathrm{kg} \mathrm{CO}_{2}$. As this process is operated at room temperature, the additional energy consumption for the cooling of the flue gas and the absorbent can be avoided [42]. The ammonium bicarbonate is used by plants as fertilizer and converts into

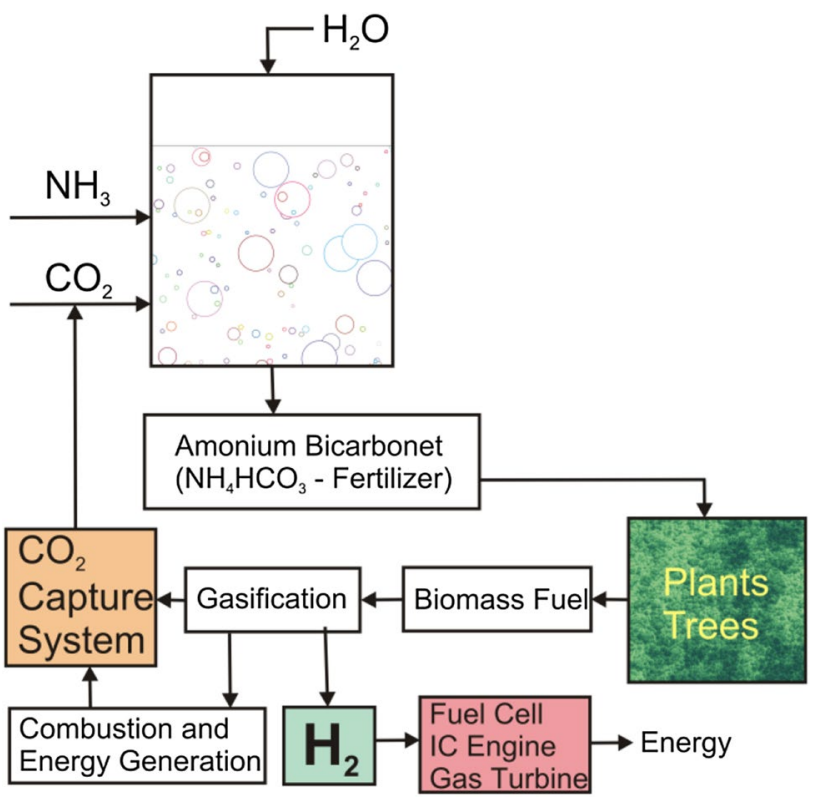

Fig. 8 Aqueous ammonia scrubbing of $\mathrm{CO}_{2}$ and ammonium bicarbonate production (prepared by Authors based on information from sources: Figueroa et al. [34], Niu et al. [42]) biomass. The gasification of biomass again would give fuel for energy generation. Therefore, $\mathrm{CCS}$ by $\mathrm{CO}_{2}$ conversion into fertilizer is most convenient and sustainable process as $\mathrm{CO}_{2}$ is recycled in the environment and the environment remains carbon neutral.

Post-combustion $\mathrm{CO}_{2}$ capture (PCC) with solar assisted chilled-ammonia-based $\mathrm{CO}_{2}$ capture system in a coal-fired power plant was undertaken for study under different meteorology conditions. It was found from the economic viewpoint that prices of the solar thermal collector and the equipment of the phase change materials (PCM) have clear impacts on the levelized costs of electricity (LCOE) and the cost of $\mathrm{CO}_{2}$ removed (CCR). The prices of solar thermal collectors vary from location-to-location resulting into varying cost of PCC system. Typically, in order to achieve lower LCOE and COR than that of the reference PCC system, the price of the vacuum tube (VT) has to be reduced to $131.02 \$ / \mathrm{m}^{2}, 91.76 \$ / \mathrm{m}^{2}$ and $57.10 \$ / \mathrm{m}^{2}$ for the location of M1 (Lhasa), M2 (Tianjin) and M3 (Xi'an), respectively [37].

\subsection{Cryogenic separation process}

Cryogenic separation is a $\mathrm{CO}_{2}$ removal process using distillation at very low temperature and high pressure. In this technique flue gas is passed through cooling media. The flue gas containing $\mathrm{CO}_{2}$ is cooled to de-sublimation temperature $\left(-100\right.$ to $\left.-135^{\circ} \mathrm{C}\right)$, where the solidified $\mathrm{CO}_{2}$ is separated from other gases. The amount of $\mathrm{CO}_{2}$ recovered can reach $90-95 \%$ of the flue gas [36]. There are two cryogenic systems: flash separation with internal cooling and separation with distillation column. Since the distillation is accompanied at extremely low temperature and high pressure, it is an energy intensive process estimated to be (600-660) $\mathrm{kWh}$ per tonne of $\mathrm{CO}_{2}$ recovered $[36,43]$. Numerous patented processes have been developed and research has mainly been focused on cost optimization [44].

There are various technologies for carbon separation and capture. A comparative study on the emerging technologies for CCS along with advantages, limitations and cost complications is shown in Table 2. Every technology has its own merits and accordingly it should be selected as per suitability.

\section{Transportation of captured $\mathrm{CO}_{2}$}

Captured $\mathrm{CO}_{2}$ is required to be transported up to suitable location. The $\mathrm{CO}_{2}$ can be transported by pipelines, trucks and ships. The mode of $\mathrm{CO}_{2}$ transportation can be selected based on separation and capturing site, and sequestration site. Morbee et al. [45] carried out numerical study 


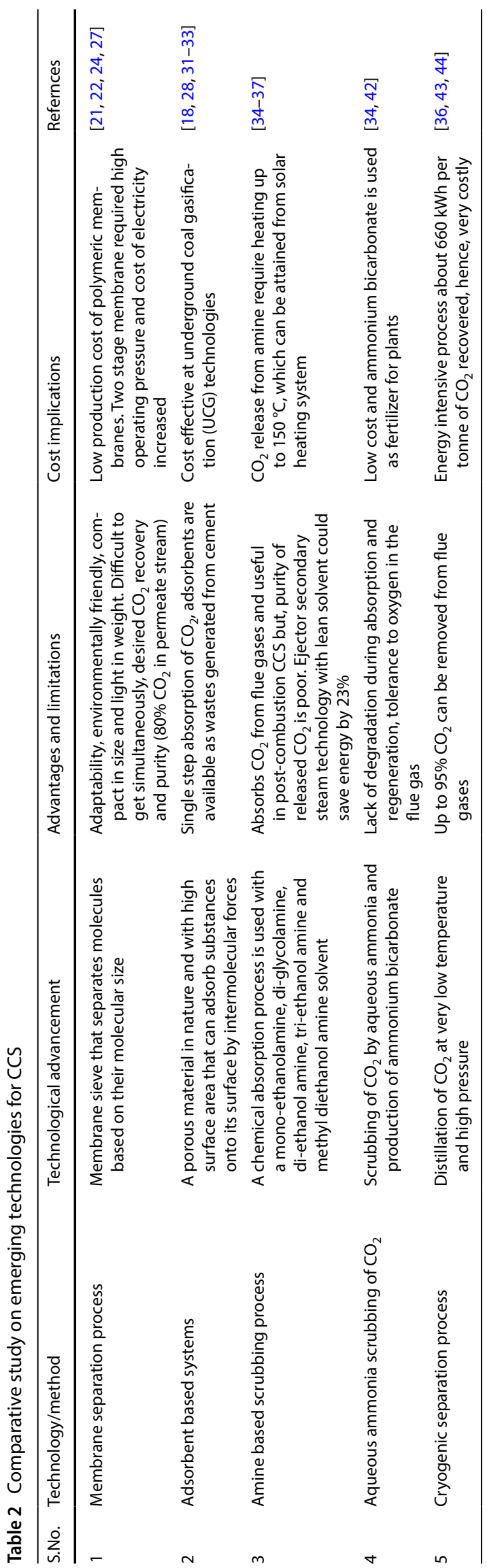

to determine the optimal EU-wide $\mathrm{CO}_{2}$ transport network for 2015-2050 and $\mathrm{EU} \mathrm{CO}_{2}$ pipeline network would reach $17,000 \mathrm{~km}$. Hasan et al. [46] carried out study on multiscale framework for the optimal design of $\mathrm{CO}_{2}$ capture, utilization, and sequestration supply chain network for cost minimization. They reported optimized cost of US $\$ 35.63$ per ton of $\mathrm{CO}_{2}$ captured and managed.

According to IPCC-2005 report [47], at present pipeline transportation is much more mature technology, but shipping of captured $\mathrm{CO}_{2}$ is economically viable under specific conditions. The transportation cost ranges 1-8 US $\$ / t$ $\mathrm{CO}_{2}$ transported for per $250 \mathrm{~km}$ pipeline or shipping for mass flow rates of 5 (high end) to 40 (low end) $\mathrm{Mt} \mathrm{CO}_{2} / \mathrm{y}$. In a study the overall costs for a European carbon capture, transport and storage supply chain was estimated in the range of $27-38 € /$ ton of $\mathrm{CO}_{2}$ [48].

\section{$6 \mathrm{CO}_{2}$ sequestration methods}

In all cases where fossil fuels are the source of energy, $\mathrm{CO}_{2}$ is inevitably produced and released into the environment. The carbon capture and sequestration (CCS) becomes essential to prevent the generated $\mathrm{CO}_{2}$ reaching into the atmosphere. Annually about $3 \mathrm{Gt}$ carbon dioxide, which is around one-eighth of current global $\mathrm{CO}_{2}$ production, needs to be sequestrated [49]. In the US, the Southeast Regional Carbon Sequestration Partnership has identified more than 900 large stationary sources of $\mathrm{CO}_{2}$ that contributes $31 \%$ of the country's $\mathrm{CO}_{2}$ stationary source emissions. The work is going on to identify the role of regional partnerships in conducting integrated field tests, carbon sequestration locations within the Gulf Coast Basin, infrastructural integrity of wells, long-term storage formations and impact of captured $\mathrm{CO}_{2}$ from power plants on the geochemistry of the saline water [50]. So far the two locations viz. deep ocean and geological structure beneath the earth have been identified as $\mathrm{CO}_{2}$ sequestration site. Generally, $\mathrm{CO}_{2}$ is stored at depths between 800 and $1000 \mathrm{~m}$ $[47,51]$. The $\mathrm{CO}_{2}$ sequestration can be done in geological formations, deep oceans, saline aquifers, tar-sands and by $\mathrm{CO}_{2}$ fixation methods as shown in Fig. 9.

\subsection{Geological sequestration of $\mathrm{CO}_{2}$}

The injection and storage of captured $\mathrm{CO}_{2}$ into the used oil wells and mined coal mines beneath the earth, is termed as geological sequestration. The geologic injection that could be considered is the use of abandoned, uneconomic coal seams. The $\mathrm{CO}_{2}$ injections in geological formations are usually performed for enhanced hydrocarbon recovery in oil and gas reservoirs, and storage and sequestration in saline aquifers. Once, $\mathrm{CO}_{2}$ is injected into the formation, 
it diffuses through the pore structure of coal and is physically adsorbed, thus retention on a permanent basis is possible. The chemical reactions between brine ions and $\mathrm{CO}_{2}$ molecules and consequent reactions with mineral grains are also important processes [52]. The $\mathrm{CO}_{2}$ geo-storage efficiency in oil wells is strongly affected by the wettability of $\mathrm{CO}_{2}$-brine-mineral system at storage conditions. Water-wetness decreases with increase in $\mathrm{CO}_{2}$-wetness, which results in reducing both structural and residual trapping capacities. Use of nano-fluid, e.g., silicon dioxide $\left(\mathrm{SiO}_{2}\right)$ nano particles, renders $\mathrm{CO}_{2}$-wet calcite to water-wet, which enhances $\mathrm{CO}_{2}$ geo-storage potentials [53].

The geologic sequestration of $\mathrm{CO}_{2}$ has higher expected retention rate and expected residence times are at least thousands of years. The consideration of carbon credits should be made on the retention ability of the geologic reservoir. The amount of $\mathrm{CO}_{2}$ that leaks into the atmosphere should be considered as the difference of the amount sequestered in the geologic formation versus the actual quantity remaining $[54,55]$. Coal beds often contain large amounts of methane. The extraction of this methane could represent a value added process. Currently, Burlington Resources is injecting 70,000 tonne of $\mathrm{CO}_{2}$ per year into a deep coal formation located in the San Juan Basin $[55,56]$. A similar small scale project was undertaken by the Alberta Research Council in Canada and reported that by using $\mathrm{CO}_{2}$ instead of water to flood the bed, there exists a higher potential to recover the methane efficiently and also sequester the $\mathrm{CO}_{2}$. While this sounds ideal, much further research is needed in this area to understand and optimize the process. Worldwide storage capabilities for $\mathrm{CO}_{2}$ within deep coal beds are estimated to be up to $150 \mathrm{Gt}[16]$.

\subsection{Deep ocean and saline aquifers $\mathrm{CO}_{2}$ sequestration}

The direct injection of $\mathrm{CO}_{2}$ into the ocean can reduce the peak atmospheric $\mathrm{CO}_{2}$ concentrations and their rate of increase. However, using this method, it is estimated that around $15-20 \%$ of the $\mathrm{CO}_{2}$ injected into the ocean will leak back into the atmosphere over hundreds of year [55].

The geologic injection may be superior to oceanic injection because of its higher expected retention period, at least thousands of years compared to that of oceanic injection of only hundreds of years [55]. Even longer residence times could be achieved if the $\mathrm{CO}_{2}$ reacted underground to form carbonate minerals, thus reducing the possibility of escape into the atmosphere [52].

Large deep formation of porous rocks is known as saline aquifers. These are basically porous sand stones and lime stones, which contain large amount of brine water in their pore space. Disposal of $\mathrm{CO}_{2}$ from stationary sources (e.g., fossil-fuelled power plants) into brackish (saline) aquifers has been suggested as a possible means for reducing emissions of greenhouse gases into the atmosphere. The $\mathrm{CO}_{2}$ at first compressed at very high pressure, about 95 bar or higher [57], and then injected into the saline aquifers, where aquifer water is replaced by the $\mathrm{CO}_{2}$ which occupies the porous space, as shown in Fig. 10.

The reactions among $\mathrm{CO}_{2}$, brine and formation minerals play an important role in formations with a large number of proton sinks, such as feldspar and clay minerals. The $\mathrm{CO}_{2}$ dissolves in formation brine. First, it simply dissolves, then equilibrium is established between the dissolved $\mathrm{CO}_{2}$ and carbonic acid $\mathrm{H}_{2} \mathrm{CO}_{3}$, which dissociates into $\mathrm{HCO}_{3}^{-}$and $\mathrm{CO}_{3}^{2-}$. About $1 \%$ of the dissolved $\mathrm{CO}_{2}$ exists as carbonic acid $\mathrm{H}_{2} \mathrm{CO}_{3}$ [58]. The reaction mechanism is shown in Eq. (4) and Eq. (5).

$$
\begin{aligned}
& \mathrm{CO}_{2}(\mathrm{~g}) \rightarrow \mathrm{CO}_{2}(\mathrm{aq}) \\
& \mathrm{CO}_{2}(\mathrm{aq})+\mathrm{H}_{2} \mathrm{O}(\mathrm{l}) \rightleftharpoons \mathrm{H}_{2} \mathrm{CO}_{3}(\mathrm{aq}) \rightleftharpoons \mathrm{H}^{+}+\mathrm{HCO}_{3}^{-} \rightleftharpoons 2 \mathrm{H}^{+}+\mathrm{CO}_{3}^{2-}
\end{aligned}
$$

Fig. 9 Technical options for $\mathrm{CO}_{2}$ sequestration (prepared by Authors based on information from sources: Metz et al. [47], Cuellar-Franca and Azapagic [51])

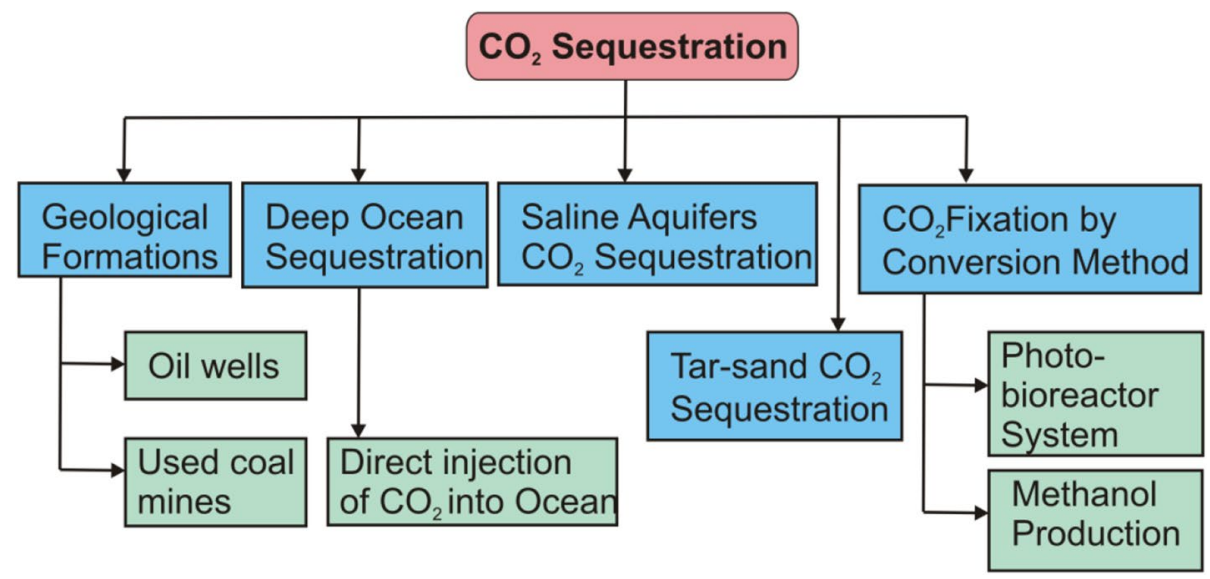

SN Applied Sciences A SPRINGER NATURE journal 


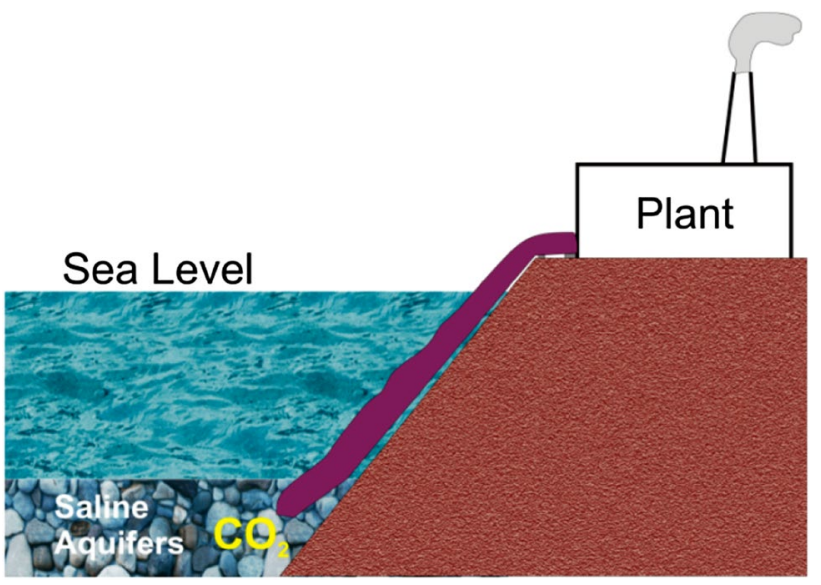

Fig. 10 Saline aquifer $\mathrm{CO}_{2}$ sequestration (prepared by Authors based on information from sources: Stewart and Hessami [55], Soong et al. [57])

Next, the carbonate anion $\mathrm{CO}_{3}^{2-}$ interacts with cations in formation water such as $\mathrm{Ca}^{2+}$ and $\mathrm{Mg}^{2+}$ to precipitate carbonate minerals. Extensive deposits of lime stone and dolomite have been formed in this way [58]. The mutual solubility of $\mathrm{CO}_{2}$ and brine affects the injection process and flow properties. First, $\mathrm{CO}_{2}$ dissolves in brine and reacts with water, forming an acid. Then, $\mathrm{H}_{2} \mathrm{O}$ dissolves into $\mathrm{CO}_{2}$ increasing the salinity of brine [59]. The solubility of $\mathrm{CO}_{2}$ in brine depends essentially on pressure, temperature, total salinity, density difference between $\mathrm{CO}_{2}$ and brine, critical $\mathrm{CO}_{2}$ saturations, etc.

The effects of contaminants such as $\mathrm{SO}_{2}$ on $\mathrm{CO}_{2}$ sequestration in saline aquifers were studied and it was reported that $\mathrm{SO}_{2}$ reaction with water would form sulphuric acid, which would lead to substantial reduction in brine $\mathrm{pH}$ due to the formation of bassanite (major) and anhydrites [57]. Currently $\mathrm{CO}_{2}$ injection into the deep geological formation is about 15 megatons of $\mathrm{CO}_{2}$ underground annually [60].

\subsection{Tar-sand $\mathrm{CO}_{2}$ sequestration}

Compressed $\mathrm{CO}_{2}$ at 200 bar and $400{ }^{\circ} \mathrm{C}$ is injected into the deep sea oil-bitumine sand bed. At the depth about 600-1000 $\mathrm{m}$ the $\mathrm{CO}_{2}$ will exist as a supercritical fluid [61] with specific gravity of somewhere between 0.6 and 0.8 . The supercritical $\mathrm{CO}_{2}$ is buoyant in the saline formation water and will rise until it encounter a seal. Bitumine is soluble in $\mathrm{CO}_{2}$ and becomes liquid, which can be extracted easily from unminable bitumine seams, as shown in Fig. 11.

\section{4 $\mathrm{CO}_{2}$ fixation by conversion methods}

Carbon dioxide fixation can be done by conversion methods such as photosynthetic conversion and methanol

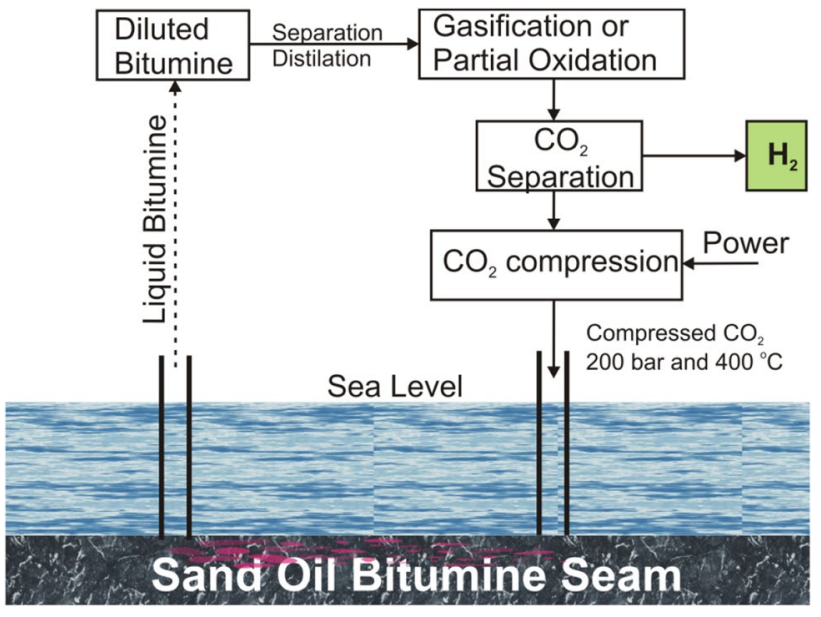

Fig. 11 Tar-sand bitumine $\mathrm{CO}_{2}$ sequestration (prepared by Authors based on information from source: Holloway [61])

production by using renewable hydrogen. The photosynthetic conversion of $\mathrm{CO}_{2}$ into carbohydrate is done in a photo-bioreactor in presence of bacteria or micro-algae under a controlled environment. A photo-bioreactor system makes use of the natural process known as photosynthesis to convert light, heat and carbon dioxide to useful products, such as carbohydrates, hydrogen and oxygen [55], is shown in Eq. (6).

$6 \mathrm{CO}_{2}(\mathrm{aq})+6 \mathrm{H}_{2} \mathrm{O}(I)+$ Light + Heat $\rightarrow \mathrm{C}_{6} \mathrm{H}_{12} \mathrm{O}_{6}(\mathrm{aq})+6 \mathrm{O}_{2}(g)$

The type of product produced in photosynthesis reaction Eq. (6), in this case glucose, depends highly on the biological strain used in the photo-bioreactor. A photobioreactor requires use of the 'flashing light effect' with light-dark cycle of $1 \mathrm{~Hz}$ frequency with a light versus dark residence time of 1:10 [55, 62].

Production of liquid hydrocarbon fuels from $\mathrm{CO}_{2}$ and water by using a concentrated solar energy source is an established technology. A life cycle assessment (LCA) analysis of the environmental impacts of sunshine-to-petrol (S2P)derived and petroleum-derived gasoline was carried out by Kim et al. [63]. Based on the LCA results, it was reported that S2P gasoline shows lower impact scores for global warming potential (GWP) than the conventional gasoline and provides external cost savings.

Another method of $\mathrm{CO}_{2}$ fixation is production of methanol from $\mathrm{CO}_{2}$ by using renewable hydrogen as shown in Eq. (7). The methanol as transportation fuel is certainly much better than the hydrogen, much easier and safer to store and distribute, and can be used in internal combustion engines [64].

$\mathrm{CO}_{2}+3 \mathrm{H}_{2} \rightarrow \mathrm{CH}_{3} \mathrm{OH}+\mathrm{H}_{2} \mathrm{O}$ 
Taking advantage of $\mathrm{CO}_{2}$-derived chemical commodities, known as carbon capture and conversion (CCC), is another methodology which may be a mile stone in the way of sustainable reduction of $\mathrm{CO}_{2}$ emission. Advances in $\mathrm{CO}_{2}$ chemical transformation with the emphasis on the energy constraints, materials, and process design are leading to promote the environmentally benign use of carbonaceous fuels and derived hydrocarbon products. But, the surface chemistry of $\mathrm{CO}_{2}$ reduction is a major challenge due to large energy barriers and requiring noticeable catalysis [65].

\section{Characterization and monitoring of $\mathrm{CO}_{2}$ storage-site}

Storage of $\mathrm{CO}_{2}$ securely in geological formations depends on number of physical and chemical mechanisms. For storage of $\mathrm{CO}_{2}$ securely and long term duration proper location of plants, infrastructure and pipelines is essential for optimum use of capital invested and subsurface capacity. Fang et al. [58] reviewed about phase behaviour of $\mathrm{CO}_{2}$ and reported that supercritical $\mathrm{CO}_{2}$ injection can avoid the prior separation of $\mathrm{CO}_{2}$ into liquid and gas phase, and also provide longer residence time than gaseous $\mathrm{CO}_{2}$ injection. The $\mathrm{CO}_{2}$ will exist as a supercritical fluid at depths about 600-1000 m [61]. Supercritical $\mathrm{CO}_{2}$ is preferred, because it is much denser and takes up much less volume than gaseous $\mathrm{CO}_{2}$; but for remaining $\mathrm{CO}_{2}$ in supercritical phase, such storage conditions are required.

\subsection{Numerical models and analysis}

Numerical modelling permits time saving and less utilization of resources for quantitative analysis of thermodynamic and geo-mechanical formation for various CCS practices. Numerous numerical models have been developed and put forward for analysis of geochemical evaluation of the $\mathrm{CO}_{2}$ injection. A prompt screening analysis for selection of suitable geological formations for $\mathrm{CO}_{2}$ injection may be obtained by using the steady-state and one-dimensional Eulerian convection-diffusion-depletion equation governing the transport and temporal evolution of an averaged or mean macro scale $\mathrm{CO}_{2}$ concentration $(C)$, as shown in Eq. (8).

$\frac{\partial C}{\partial t}+\bar{U}^{*} \cdot \bar{\nabla} C-\bar{D}^{*} \cdot \bar{\nabla} \bar{\nabla} C+\bar{K}^{*} C=0$

where, $\bar{\nabla}=\partial / \partial \overline{\mathrm{R}}$, represents the gradient with respect to the continuum scale position vector, $\bar{R}$ [45]. Continuity of the $\mathrm{CO}_{2}$ flux across the porous bed inlet requires imposing the boundary condition: $C=C_{\text {in }}$ at $x=0$ and $\frac{\partial C}{\partial x}=0$ at $x=L$.
The efficiency of a $\mathrm{CO}_{2}$ storage/sequestration process is given by Eq. (9) [45].

$\eta_{\mathrm{CO}_{2}}=\frac{\text { Total number of } \mathrm{CO}_{2} \text { molecules stored or sequestrated in the bed }}{\text { Total number of } \mathrm{CO}_{2} \text { molecules entred into the bed }}$

A comparative study on experimental and numerical simulation was carried out by Izgec et al. [66], which reported that amount of dissolved particles and the total amount of particles that are blocking the throat increases with respect to increase in the reaction frequency of forward reaction (dissolution). This leads to decrease in permeability. They reported that because of several uncertainties and approximations such as chemical complexity of injection induced water- $\mathrm{CO}_{2}$-rock interaction processes, the present state-of-the-art numerical models are not able to give a complete quantitative prediction of geochemical evolution of $\mathrm{CO}_{2}$ injection.

Rutqvist and Tsang [67] carried out a numerical study of hydro-mechanical changes during a deep underground injection of supercritical $\mathrm{CO}_{2}$ in a hypothetical brine aquifer/caprock system and reported that hydro-mechanical changes were induced in the lower part of the caprock near its contact with the injection zone. The flow dynamics study during $\mathrm{CO}_{2}$ disposal in saline aquifers has shown the $\mathrm{CO}_{2}$ flow pattern in aquifers, but stressed on to carry out quantitatively realistic studies with detailed representation of aquifer heterogeneities and comprehensive description of coupled processes [16].

Mathias et al. [68] worked on governing equations for $\mathrm{CO}_{2}$ injection into a slightly compressible brine aquifer with a vertical pressure equilibrium assumption and carried out a new similarity solution by using the method of matched asymptotic expansions and prepared a dimensionless parameter equation. A large time approximation of the solution was then extended to account for inertial effects using the Forchheimer equation and allowed the slight compressibility in the fluids and formation. The validation of both solutions was explored by comparison with equivalent finite difference solutions and revealed that the new method can provide robust and mathematically rigorous solutions for screening level analysis, where numerical simulations may not be justified or cost effective.

Javadpour [52] worked on an advanced up-scaling theory to relate the tiny pore scale events to the macroscopic properties of interest. The dispersion effects of impulse and $\mathrm{CO}_{2}$ injection in field disturbance was studies by using macro transport theory, which is the extension of the celebrated Taylor-Aris dispersion theory $[69,70]$ and reported that dispersion process for the impulse and $\mathrm{CO}_{2}$ injection in field disturbances was the same [71, 72]. Hongjun et al. [73] carried out sensitivity analysis of $\mathrm{CO}_{2}$ sequestration in saline aquifers and 


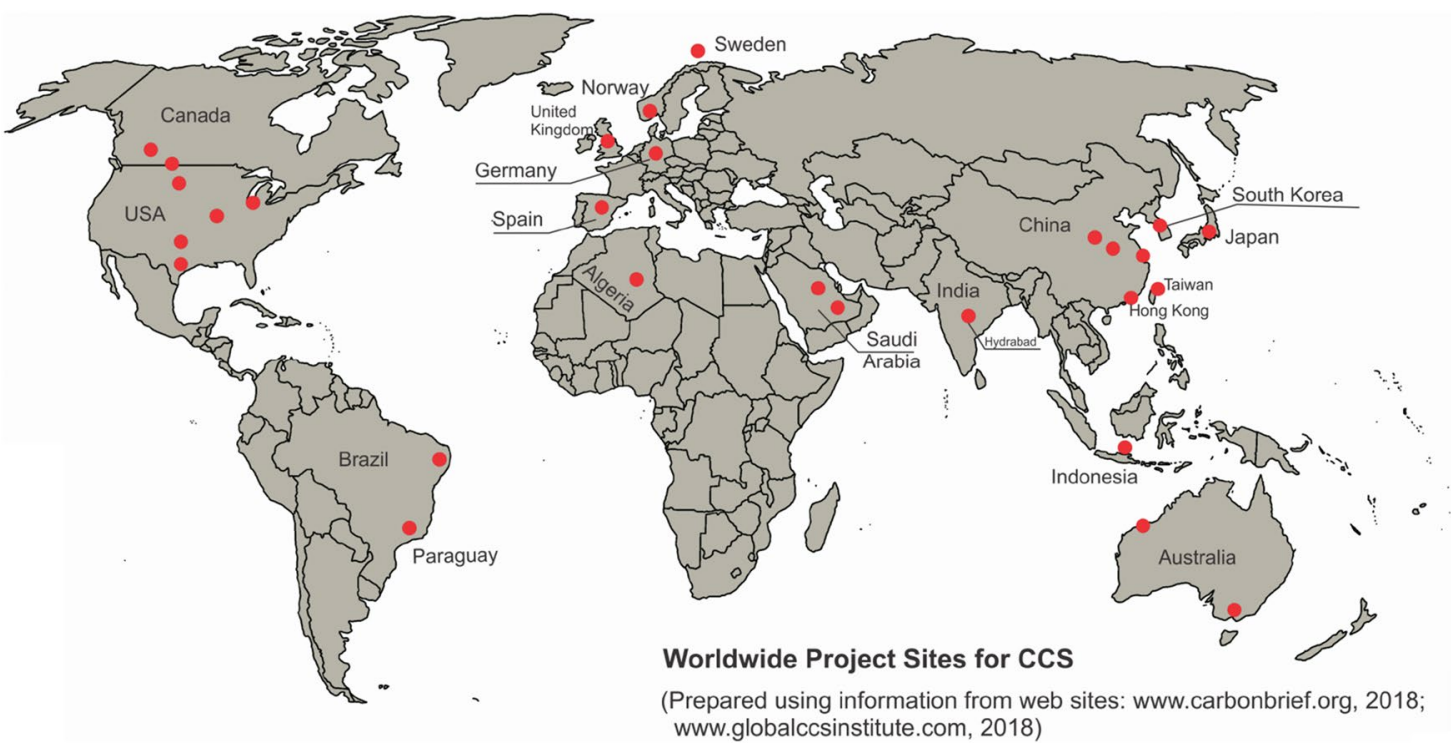

Fig. 12 Worldwide sites for CCS at pilot stage (prepared by Authors based on information from sources: [86, 87])

reported that during injection phase only about $5-10 \%$ $\mathrm{CO}_{2}$ dissolves in the brine and rest of the $\mathrm{CO}_{2}$ migrates in the gas phase. After termination of injection the $\mathrm{CO}_{2}$ continues to dissolve mainly due to the contact of gas with brine and the efficiency of dissolution depends on many factors including brine salinity, vertical to horizontal permeability ratio and residual phase saturations; but, hysteresis and mineral trapping should be investigated further.

A numerical simulation was carried out by Beni et al. [74] to provide an insight into flow and transport processes to quantify the $\mathrm{CO}_{2}$ storage potential of selected sites in North Rhine Westphalia (NRW) in Germany. A numerical code TOUGHREACT [75, 76] was used to study three trapping mechanisms: hydrodynamic trapping, dissolution trapping and mineral trapping, for $\mathrm{CO}_{2}$ injected into the Bunter sandstone formations. The injected $\mathrm{CO}_{2}$ plume initially migrated towards the top of the reservoir due to buoyancy until it reached the confining layer. Then, it spread laterally and dissolved partially in the formation water. This dissolution of $\mathrm{CO}_{2}$ resulted in an increase of brine density causing the $\mathrm{CO}_{2}$ enriched water to migrate downward [74]. A retrofit of a $\mathrm{CO}_{2}$ capture pilot plant using superstructure and ratebased model was developed. It was optimized and found that thermal energy and total energy consumption in the optimal retrofit process were reduced by about $59 \%$ and $27 \%$, respectively [77]. The optimum $\mathrm{CO}_{2}$ injection pressure depends on the aquifer depth, while the effects of salinity and temperature are negligible. An increment in aquifer depth from 0.8 to $1.4 \mathrm{~km}$ causes the optimum injection pressure increment from 19.55 to $42 \mathrm{MPa}$ [78].
Azin et al. [79] carried out numerical analysis for injection of $\mathrm{CO}_{2}$ into saline aquifer by using finite element method and reported that instability occurs earlier and grows faster with increase in Rayleigh number, which affect the wave number. But, number of assumptions imposes the limitations to the numerical analysis. The numerical models are good for optimal prediction of parameters, but uncertainty associated with sequestration methods is a major hindrance to practical application of developed models. The CCS technologies in action are still new and it is not known exactly the full consequences of such abatement technologies, in terms of environmental consequences or in terms of efficiency, once the leakage problem is considered [10].

Once the $\mathrm{CO}_{2}$ injection starts, a site monitoring and verification program of $\mathrm{CO}_{2}$ distribution is required in order to observe key features and risk assessment, manage the injection process, describe and identify leakage risk and surface escapes, provide early warnings of failure near the reservoir and verify the storage for accounting and crediting. For $\mathrm{CO}_{2}$ storage to succeed, a site must have sufficient injection storage capacity to sequester point-source volumes, sufficient capacity to store the total emissions of an injection project over its lifetime and effective storage.

\section{Economic analysis of CCS methods}

Storage cost of $\mathrm{CO}_{2}$ depends on many factors including the type of storage options, location, depth and characteristics of the storage reservoir formations. The $\mathrm{CO}_{2}$ 


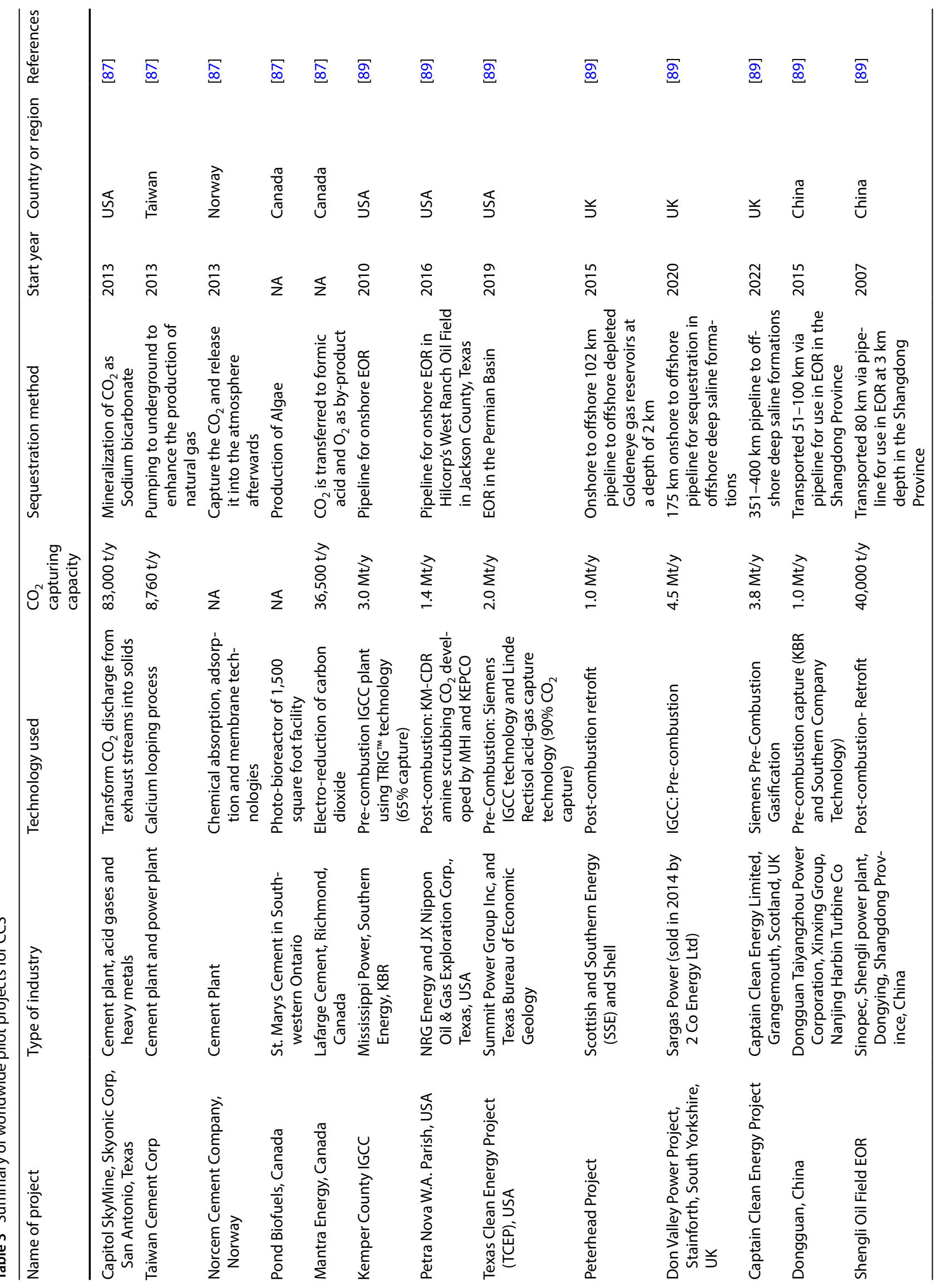


mitigation costs for electricity generation with CCS [8] can be calculated by using Eq. (10).

$\mathrm{CO}_{2}$ mitigation costs $=\frac{\mathrm{COE}_{\mathrm{CCS}}-\mathrm{COE}_{\text {ref }}}{m_{\mathrm{CO}_{2} \text {,ef }}-m_{\mathrm{CO}_{2}, \mathrm{CCS}}}$

where COE is the cost of electricity $(\$ / \mathrm{kWh})$ and $m$ is the $\mathrm{CO}_{2}$ emission factor $(\mathrm{kg} / \mathrm{kWh})$ with the $\mathrm{CCS}$ and reference or without CCS. The Eq. (10) is applicable when hydrogen produced with $\mathrm{CO}_{2}$ capture replaces conventionally produced hydrogen.

In an economic analysis it was reported that the carbonates over amine-based systems has benefits of significantly lower energy requirement for regeneration [29, 34]. In a power plant for the capture and sequestration up to $90 \%$ of the $\mathrm{CO}_{2}$ generated, an additional cost of US $\$ 2 / \mathrm{kWh}$ would be added to the production costs $[54,55]$. Studies suggested that CCS would increase the hydrogen supply costs at filling stations by $25-30 \%$; some studies indicate even higher costs. The cost of the fuel is the principal component in this extra cost when hydrogen is produced from natural gas while the capital cost is the most important component when hydrogen is produced from coal [2]. The capture of $\mathrm{CO}_{2}$ would add about $25-30 \%$ of the cost of production to the cost of producing hydrogen [9].

According to IPCC [47] the estimated total cost for saline aquifer storage ranges from US $\$ 0.2-12.0 /$ ton $\mathrm{CO}_{2}$. Kuramochi et al. [80] carried out a comprehensive review study to assess $\mathrm{CO}_{2}$ capture options for various industrial processes in details. They reported that standardized key performance data could be a useful input to various energy-economic models that wants to incorporate $\mathrm{CO}_{2}$ capture from industries. An engineering-economic analysis of pre-combustion gas-turbine combined cycles (IGCC and IRCC) with $\mathrm{CO}_{2}$ capture was carried out by Lorenzo et al. [81] and their economic performance was evaluated in terms of the break-even electricity selling price. The results indicate that the proposed pre-combustion power plant efficiency values (37\% and $43.7 \%$ for the IGCC and the IRCC, respectively) were significantly lower compared to a conventional plant value (55.3\%). Flexible CCS as compared to normal CCS provides more system benefits, generator's net efficiency and capacity, which could make flexible $\mathrm{CCS}$ an economic $\mathrm{CO}_{2}$ emission reduction strategy [82].

Accomplishing the significant cost reduction will require not only a strong and sustained level of research and development, but also a substantial level of commercial deployment, which, in turn, demands a significant market for $\mathrm{CO}_{2}$ capture technologies [18]. In order to place the risks into perspective, the comparison risks involved in $\mathrm{CO}_{2}$ transport and storage activities can be 
Table 4 The earth and atmospheric hazards due to risk elements related to CCS (prepared by Authors based on information from sources: Koornneef et al. [83], Selvadurai [92], Song and Zhang [93]

\begin{tabular}{llll}
\hline Source of leakage & Expected hazard level & \\
\cline { 2 - 4 } & Crustal deformation & $\begin{array}{l}\text { Ground water degra- } \\
\text { dation }\end{array}$ & Atmospheric release \\
\hline Well leakage & High & Highest & Highest \\
Fault leakage & Highest & High & High \\
Caprock leakage & Moderate & Moderate & Moderate \\
Pipeline leakage & High & NA & High \\
\hline
\end{tabular}

done; however it is not judicious to use the results of such a comparison to provide any argument for the acceptance/rejection of these risks. The systematic comparison between the risks of $\mathrm{CO}_{2}$ pipelines and $\mathrm{CO}_{2}$ storage is rather difficult and could not be done within limited study [83]. Deployment of hydrogen vehicles on road will lead to abatement of $\mathrm{CO}_{2}$, but it is strongly dependent not only on vehicle cost, but also on global marginal abatement cost [84]. Various incentive programs can accelerate the development and deployment of improved $\mathrm{CO}_{2}$ capture systems. The Government actions that significantly limit $\mathrm{CO}_{2}$ emission to the atmosphere ultimately are needed to realize considerable and continual reductions in the future cost of $\mathrm{CO}_{2}$ capture [18].

\section{Opportunities and challenges ahead in CCS}

The carbon sequestration beneath the ocean and saline aquifers has great potential and can save millions of tonnes of $\mathrm{CO}_{2}$ emission to the atmospheres. Over the period, the stored carbon again may convert into fuel, which may be explored in future. On the contrary, there are challenges and problems related to the stored carbon. Injection of $\mathrm{CO}_{2}$ into saline aquifers will give rise to a variety of coupled physical and chemical processes, including pressurization of reservoir fluids, immiscible displacement of an aqueous phase by the $\mathrm{CO}_{2}$ phase, partial dissolution of $\mathrm{CO}_{2}$ into the aqueous phase, chemical interactions between aqueous $\mathrm{CO}_{2}$ and primary aquifer minerals, and changes in effective stress which may alter aquifer permeability and porosity, and may give rise to increase in seismic sensitivity as well.

Non-isothermal effects may arise from phase partitioning, chemical reactions, and compression/decompression effects. Many of the important processes involve non-linear effects and dependencies on pressure, temperature, and fluid composition. If geo-sequestration of $\mathrm{CO}_{2}$ is to be employed as a key emission reduction method in the global efforts to mitigate against climate change, simple yet robust screening of the risks of disposal in brine aquifers will be needed [68]. The CCS technologies require water and huge amount of waste water in generated; therefore cost-effective water treatment technologies are also required for site-specific cases [85].

\subsection{CCS technologies as opportunities and worldwide projects}

Efforts have been started long back for CCS technologies and numbers of projects are under way for CCS worldwide. Many countries including USA, Canada, Brazil, United Kingdom, Germany, Spain, Norway, Sweden, Algeria, Saudi Arabia, India, Australia, China, Indonesia, China, Taiwan, Hong Kong, Japan, South Korea, etc. are working on CCS. Most of the CCS sites are concentrated around the coal fields, oil fields and fuel processing plants, where low carbon fuel is produced along with CCS. Worldwide projects and sites for CCS are shown in Fig. 12 [86, 87]. Germany started it's CCS program on 24th August 2012 with an act on the demonstration and use of the technology for the capture, transport and permanent storage of $\mathrm{CO}_{2}$ [87].

The cement industries and power plants are the most significant industrial sectors with high $\mathrm{CO}_{2}$ discharge. Pilot and demonstration projects are essential to develop carbon capture for this major $\mathrm{CO}_{2}$ discharging sector. A comprehensive review on worldwide pilot projects for CCS along with technologies used, $\mathrm{CO}_{2}$ capturing capacity, sequestration method and start of year is shown in Table 3 [87-89].

\section{$9.2 \mathrm{CO}_{2}$ leakage hazards}

After storage of $\mathrm{CO}_{2}$ into different formations, there is risk of leakage. A number of circumstances, such as leakage through existing or induced faults and fractures, leakage along a spill point, caprock failure or permeability increase and leakage along a well and wellhead failure, are possible for the leakage of $\mathrm{CO}_{2}$ from the target reservoirs [83]. Injection of captured carbon at depth of sea may contaminate ground water through leakage. This leads to understanding for design and implementation of appropriate monitoring and control system, both for serving the purpose 


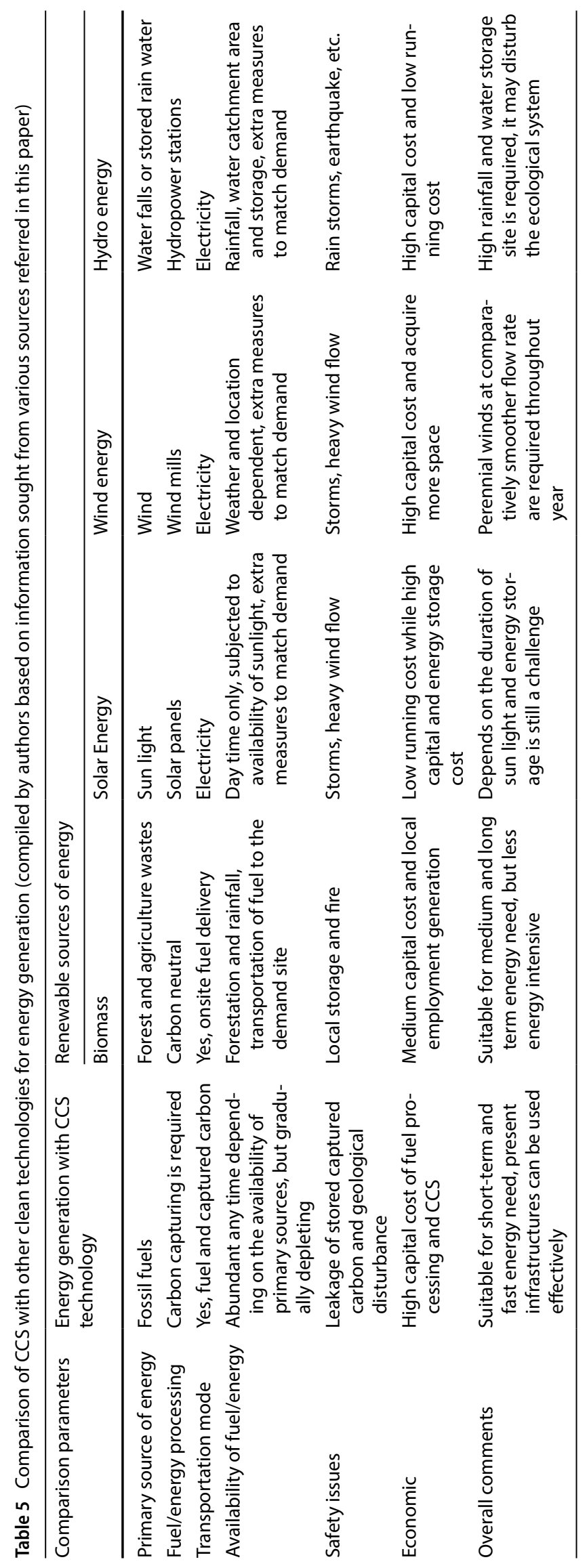


and assurance of environmental safety [90]. In the storage of supercritical $\mathrm{CO}_{2}$, if there is any leakage of stored $\mathrm{CO}_{2}$, then it will rise in saline water until it encounters a seal as the supercritical $\mathrm{CO}_{2}$ floats in the saline formation water. Therefore, determination of the effectiveness of such seals will be a necessary part for the appraisal of suitable sites for $\mathrm{CO}_{2}$ storage. The seal integrity of shattered oil and gas wells will be relatively well known, but the deep saline aquifers will be less well-understood. So, considering such formations for secure $\mathrm{CO}_{2}$ storage will represent significant challenges. The uncertainties in quantifying leakage rates and expected cost of leakage risk is unlikely to significantly hinder global CCS deployment or the effectiveness of policy for mitigating climate change [91].

Table 4 shows the earth and atmospheric hazards because of various risk elements [83,92,93]. The well leakage has highest risk for ground water and atmosphere. The leakage of $\mathrm{CO}_{2}$ in geological formations may dissolve the rocks/saline aquifers leading to the land sliding and $\mathrm{CO}_{2}$ concentrating near leakage area. The increase in $\mathrm{pH}$ value of saline water due to dissolving of $\mathrm{CO}_{2}$ into water may affect the life-cycle of sea creatures.

\subsection{Development in cost effective technologies}

The CCS technologies today are well understood and effective, and can probably provide what is expected. However, there are some outstanding technical concerns including development of indigenous and lower-cost CCS technologies, integration and deployment of CCS technologies, regulations and protocols for sequestration site characterization, characterization of sequestration site leakage and mitigation, and technical basis for monitoring, verification, operational protocols and risk characterization. There are multiple hurdles including cost-effective and viable technologies for implementing CCS technologies [36].

There are many issues, which are not technical; but related to technical readiness and maximizing early investment in CCS. The developed countries such as USA, Japan, Germany, UK, etc. should take lead in the field of CCS. This in turn will promote potential CCS users in making key investment decisions. A global assessment framework should be prepared as a policy priority. The developing countries may be given carbon credit to develop and deploy the CCS system in their power plants and industrial organisations. The infrastructure to transport $\mathrm{CO}_{2}$ (e.g. trucks, pipelines) is a key enabler for commercial deployment of CCS system [48]. Initially, some incentives and Government actions for this infrastructure are needed to build networks sufficient for large-scale commercial CCS deployment.

\subsection{Regulatory and policy issues for CCS}

The CCS technologies are striving to gain traction in the set of options for dealing with climate change, but growth is very slow due to absence or low intervention of government action on climate change, public scepticism, increasing costs, and advances in other options including renewables and shale gas [60]. A comprehensive evaluation of various technologies or methods is necessary for reducing or avoiding $\mathrm{CO}_{2}$ emission to the environment. There is need for formulating and implementing overall policy that should be successful not only in reducing $\mathrm{CO}_{2}$, but also in saving energy and generating jobs in the economy of the twenty-first century [49].

The R\&D activities are underway to conquer the technological hurdles to the effective implementation of CCS; however, the legislative framework is required for proper implementation of technologies and monitoring of the substantial role in the mitigation of carbon emission. The CCS regulations should be liable for the regulatory treatment of $\mathrm{CO}_{2}$ and other gases in the $\mathrm{CO}_{2}$ stream, monitoring, verification and remedial strategies to ensure whether the CCS can effectively mitigate carbon emissions and provide avenue to future hydrocarbon supplies.

Moreover, the coordination between central and state governments about their roles in deployment of CCS is required. The authority and responsibilities should be fixed for granting permission and monitoring the various processes. The proper regulation policies certainly will help to attract commercial players into the CCS market. The CCS will help in mitigation of extra $\mathrm{CO}_{2}$ liberation associated with heavy oil, coal-to-liquids (CTL) and gasto-liquids (GTL) technologies and, thereby, help render these resources more readily usable even under carbon constraint world.

Based on literature review, the authors have tried to summarise the energy receiving from different sources and there comparative merits and demerits. Comparison of CCS with other clean technologies for energy generation is shown in Table 5 (compiled by authors based on information sought from various sources referred in this paper). The renewable sources of power generation are carbon free and sustainable in nature, but their availability at all time and portability is one of the challenges. The limitation and energy supply gap between conventional sources and renewable sources of energy can be bridged by use of fossil fuels with CCS technology. Instead of using individual system or energy generation methodology, the hybrid system is suggested for wider acceptability and sustainable power generation. The renewable sources of energy 
should be used as major power generation sources and fossil fuels with CCS technology can be used as supplementary sources for peak power generation and standby mode.

\section{Conclusions}

Most of the energy requirements for industrial application and transportation activities are fulfilled from fossil fuels (e.g., diesel, gasoline, natural gas and coal), which is resulting into addition of $\mathrm{CO}_{2}$ as greenhouse gas into the environment. By year 2030, the primary production of energy from coal will reach to 3976 Mtoe and discharge of $\mathrm{CO}_{2}$ into environment about $38749 \mathrm{MtCO}_{2}$ per year. The compilation work is summarised as follow:

- The $\mathrm{CO}_{2}$ capture techniques, such as membrane separation process can separate about $90 \%$ of $\mathrm{CO}_{2}$, amine scrubbing can separate above $85 \%$ of $\mathrm{CO}_{2}$ from flue gases emitted from fossil fuel based electrical generators, membrane, molecular sieve and desiccant adsorption technologies are in use.

- Geological and oceanic injection techniques are having good potential for $\mathrm{CO}_{2}$ sequestration and worldwide capacity of about $2200 \mathrm{GtC}$, but its leakage and monitoring aspects are yet to be finalized.

- More than 50 projects on CCS are going on worldwide, but the uncertainty around global climate change negotiation may somehow affect large-scale demonstration projects on CCS.

- The sequestration of $\mathrm{CO}_{2}$ was found to be a challenging problem and require the economic viability. Decrease in associated costs and practical solutions may be found as mix of technologies and the local circumstances where CCS is to be adopted.

- The research community should have coordination between the policy makers and the environmental community. The common public should be brought into confidence and be educated on the possibilities and limitations of the CCS approaches.

\section{Compliance with ethical standards}

Conflict of interest The authors declare that they have no conflict of interest.

\section{References}

1. World Bank Data (2013) http://data.worldbank.org/indicator/ EG.USE.COMM.FO.ZS?end=2013\&start=1992. Accessed on 3 Jan 2017

2. World Energy Technology Outlook - 2050 (2006) European Commission, Brussels

3. Salvi BL, Subramanian KA (2015) Sustainable development of road transportation sector using hydrogen energy system. Renew Sustain Energy Rev 51:1132-1155. https://doi. org/10.1016/j.rser.2015.07.030

4. Duncan RC (2001) World energy production, population growth and the road to the Olduvai gorge. Popul Environ 22:503-522. https://doi.org/10.1023/A:1010793021451

5. Muda N, Pin TJ (2012) On prediction of depreciation time of fossil fuel in Malaysia. J Math Stat 8(1):136-143

6. Mitchell AC, Freeman R (2013) Carbon capture and sequestration: development efforts and outlook, pp 1-100

7. Das LM (1991) Safety aspects of a hydrogen-fuelled engine system development. Int J Hydrog Energy 16(9):619-624

8. National Hydrogen Energy Road Map (2006) National Hydrogen Energy Board, Ministry of New and Renewable Energy, Government of India, 2006

9. Damen K, Troost MV, Faaij A (2007) Turkenburg W (2007) A comparison of electricity and hydrogen production systems with $\mathrm{CO}_{2}$ capture and storage-part B: Chain analysis of promising CCS options. Prog Energy Combust Sci 33:580-609

10. Wang W, Cao Y (2012) A combined thermodynamic and experimental study on chemical-looping ethanol reforming with carbon dioxide capture for hydrogen generation. Int J Energy Res 1:1. https://doi.org/10.1002/er.2976

11. Kama AAL, Fodha M, Lafforgue G (2013) Optimal carbon capture and storage policies. Environ Model Assess 18:417-426. https:// doi.org/10.1007/s10666-012-9354-y

12. Ouyang S, Hsu H-W, Tong L-T, Liao C-W, Hu RY-Z (2011) Carbon capture and sequestration technology development in ITRI. Sustain Environ Res 21(1):21-28

13. Isehunwa OS, Makinde AA, Olamigoke O (2006) Carbon(IV) oxide capture and sequestration in Nigeria: Prospects and challenges. In: Society petroleum engineers-Nigeria annual international conference and exhibition 2006, NAICE 2006

14. Bauer N, Edenhofer O, Held H, Kriegler E (2005) Uncertainty of the role of carbon capture and sequestration within climate change mitigation strategies. In: Greenhouse Gas Control Technologies, pp 931-939

15. Hitchon B (1996) Aquifer disposal of carbon dioxide. Geoscience Publishing, Sherwood Park

16. Pruess K, Garcia J (2002) Multiphase flow dynamics during $\mathrm{CO}_{2}$ disposal into saline aquifers. Environ Geol 42:282-295

17. Audus $\mathrm{H}$ (1997) Greenhouse gas mitigation technology: an overview of the $\mathrm{CO}_{2}$ capture and sequestration studies and further activities of the IEA greenhouse gas R\&D programme. Energy 22(2/3):217-221

18. Rubin ES, Mantripragada H, Marks A, Versteeg P, Kitchin J (2012) The outlook for improved carbon capture technology. Prog Energy Combust Sci 38:630-671

19. Herzog HJ (2001) What future for carbon capture and sequestration. Environ Sci Technol 35(7):148A-153A

20. Rao AB, Rubin ES (2002) A technical, economic and environmental assessment of amine-based $\mathrm{CO}_{2}$ capture technology for power plant greenhouse gas control. Environ Sci Technol 36(20):4467-4475

21. Adewole JK, Ahmad AL, Ismail S (2013) Leo CP (2013) Current challenges in membrane separation of $\mathrm{CO}_{2}$ from natural gas: 
a review. Int J Greenhouse Gas Control 17:46-65. https://doi. org/10.1016/j.jiggc.2013.04.012

22. Zhang Y, Sunarso J, Liu S, Wang R (2013) Current status and development of membranes for $\mathrm{CO}_{2} / \mathrm{CH}_{4}$ separation: a review. Int J Greenhouse Gas Control 12:84-107. https://doi. org/10.1016/j.ijggc.2012.10.009

23. Hasebe S, Aoyama S, Tanaka M, Kawakami H (2017) $\mathrm{CO}_{2}$ separation of polymer membranes containing silica nanoparticles with gas permeable nano-space. J Membr Sci 536:148-155. https:// doi.org/10.1016/j.memsci.2017.05.005

24. Mat NC, Lipscomb GG (2017) Membrane process optimization for carbon capture. Int J Greenhouse Gas Control 62:1-12. https ://doi.org/10.1016/j.ijggc.2017.04.002

25. Hussain A, Hägg M-B (2010) A feasibility study of $\mathrm{CO}_{2}$ capture from flue gas by a facilitated transport Membrane. J Membr Sci 359:140-148. https://doi.org/10.1016/j.memsci.2009.11.035

26. Luis P, Van Gerven T, Van der Bruggen B (2012) Recent developments in membrane-based technologies for $\mathrm{CO}_{2}$ capture. Prog Energy Combust Sci 38:419-448. https://doi.org/10.1016/j. pecs.2012.01.004

27. Brunetti A, Scura F, Barbieri G, Drioli E (2010) Membrane technologies for $\mathrm{CO}_{2}$ separation. J Membr Sci 359:115-125. https ://doi.org/10.1016/j.memsci.2009.11.040

28. Li L, Zhao N, Wei W, Sun Y (2013) A review of research progress on $\mathrm{CO}_{2}$ capture, storage, and utilization in Chinese Academy of Sciences. Fuel 108:112-130

29. Rochelle G, Chen E, Dugas R, Oyenakan B, Seibert F (2006) Solvent and process enhancements for $\mathrm{CO}_{2}$ absorption/stripping. In: Annual conference on capture and sequestration, Alexandria, VA

30. Figueroa JD, Fout $T$, Plasynski $S$, Mcllvried $H$, Srivastava RD (2008) Advances in $\mathrm{CO}_{2}$ capture technology-The U.S. Department of Energy's Carbon Sequestration Program. Int J Greenhouse Gas Control 2:9-20. https://doi.org/10.1016/s1750 -5836(07)00094-1

31. Bobicki ER, Liu Q, Xu Z, Zeng H (2012) Carbon capture and storage using alkaline industrial wastes. Prog Energy Combust Sci 38:302-320. https://doi.org/10.1016/j.pecs.2011.11.002

32. Roddy DJ, Younger PL (2010) Underground coal gasification with CCS: a pathway to decarbonising industry. Energy Environ Sci 3:400-407

33. Self SJ, Reddy Bale V, Rosen Marc A (2012) Review of underground coal gasification technologies and carbon capture. Int J Energy Environ Eng 2012(3):16. https://doi. org/10.1186/2251-6832-3-16

34. Figueroa JD, Fout T, Plasynski $S$, Mcllvried $H$, Srivastava RD (2008) Advances in $\mathrm{CO}_{2}$ capture technology-The U.S. Department of Energy's Carbon Sequestration Program. Int J Greenhouse Gas Control 2:9-20. https://doi.org/10.1016/s1750 -5836(07)00094-1

35. Veawab A, Aroonwilas A, Tontiwachwuthiku P (2002) $\mathrm{CO}_{2}$ absorption performance of aqueous alkanolamines in packed columns. Fuel Chem Div P Repr 47:49-50

36. Leung DYC, Caramanna G, Maroto-Valer MM (2014) An overview of current status of carbon dioxide capture and storage technologies. Renew Sustain Energy Rev 2014(39):426-443. https ://doi.org/10.1016/j.rser.2014.07.093

37. Luis $\mathrm{P}(2016)$ Use of monoethanolamine (MEA) for $\mathrm{CO}_{2}$ capture in a global scenario: consequences and alternatives. Desalination 380:93-99. https://doi.org/10.1016/j.desal.2015.08.004

38. Reddicka C, Lib C, Sorina M, Sapoundjiev H (2014) Lowering the energy cost of carbon dioxide capture using ejectors for waste heat upgrading. Energy Procedia 63:715-726. https://doi. org/10.1016/j.egypro.2014.11.079

39. Reddick C, Sorin M, Sapoundjiev H, Aidoun Z (2016) Carbon capture simulation using ejectors for waste heat upgrading. Energy 100:251-261. https://doi.org/10.1016/j.energy.2016.01.099
40. Li Q, Gupta S, Tang L, Quinn S, Atakan V, Riman RE (2016) A novel strategy for carbon capture and sequestration by rHLPD processing. Front Energy Res 3, Art. No. 53. https://doi.org/10.3389/ fenrg.2015.00053

41. McCutcheon J, Wilson SA, Dipple GM, Southam G (2015) $\mathrm{CO}_{2}$ capture and storage by mineral carbonation utilization of chrysotile mine tailings and microbially accelerated carbonate mineral precipitation reactions as a strategy for in situ carbon sequestration. In: 5th international conference on accelerated carbonation for environmental and material engineering 2015, pp 476-477

42. Niu Z, Guo Y, Zeng Q, Lin W (2013) A novel process for capturing carbon dioxide using aqueous ammonia. Fuel Process Technol 108:154-162. https://doi.org/10.1016/j.fuproc.2012.05.028

43. Gottlicher G, Pruschek R (1997) Comparison of $\mathrm{CO}_{2}$ removal systems for fossil fuelled power plants. Energy Convers Manag 38:S173-S178

44. Tuinier MJ, Annaland MVS, Kramer GJ, Kuipers JAM (2010) Cryogenic $\mathrm{CO}_{2}$ capture using dynamically operated packed beds. Chem Eng Sci 65:114-119

45. Morbee J, Serpa J, Tzimas E (2012) Optimised deployment of a European $\mathrm{CO}_{2}$ transport network. Int J Greenhouse Gas Control 7:48-61. https://doi.org/10.1016/j.ijggc.2011.11.011

46. Hasan MMF, First EL, Boukouvala F, Floudas CA (2015) A multiscale framework for $\mathrm{CO}_{2}$ capture, utilization, and sequestration: CCUS and CCU. Comput Chem Eng 81:2-21. https://doi. org/10.1016/j.compchemeng.2015.04.034

47. Metz B, Davidson O, de-Coninck H, Loos M, Meyer L (2005) IPCC special report on carbon dioxide capture and storage, intergovernmental panel on climate change. Cambridge University Press. http:// www.ipcc.ch/pdf/special-reports/srccs. Accessed 10 Dec 2014

48. d'Amore F, Bezzo F (2017) Economic optimisation of European supply chains for $\mathrm{CO}_{2}$ capture, transport and sequestration. Int J Greenhouse Gas Control 65:99-116. https://doi.org/10.1016/j. ijggc.2017.08.015

49. Snieder $R$, Young $T$ (2009) Facing major challenges in carbon capture and sequestration. GSA Today 19(11):36-37

50. Hill G, Esposito R, Rhudy R, Sams K (2008) Development of an integrated carbon capture, separation and geologic storage pilot: a technical research project of the Southeast Regional Carbon Sequestration Partnership Conference Proceedings-2009 AIChE Spring National Meeting and 5th Global Congress on Process Safety, p 3

51. Cuellar-Franca RM, Azapagic A (2015) Carbon capture, storage and utilisation technologies: a critical analysis and comparison of their life cycle environmental impacts. J CO2 Util 9:82-102. https://doi.org/10.1016/j.jcou.2014.12.001

52. Javadpour $\mathrm{F}$ (2009) $\mathrm{CO}_{2}$ injection in geological formations: determining macroscale coefficients from pore scale processes. Transp Porous Med 79:87-105. https://doi.org/10.1007/s1124 2-008-9289-6

53. Al-Anssaria $S$, Arif $M$, Wang $S$, Barifcani A, Lebedev $M$, Iglauer $\mathrm{S}$ (2017) $\mathrm{CO}_{2}$ geo-storage capacity enhancement via nanofluid priming. Int J Greenhouse Gas Control 63:20-25. https://doi. org/10.1016/j.ijggc.2017.04.015

54. Herzog $\mathrm{H}$ (1999) An introduction to $\mathrm{CO}_{2}$ separation and capture technologies. Energy Laboratory Working Paper, Massachusetts Institute of Technology, Cambridge. https://sequestration.mit. edu/pdf/introduction_to_capture.pdf. Accessed on 19 June 2017

55. Stewart C, Hessami M (2005) A study of methods of $\mathrm{CO}_{2}$ capture and sequestration - the sustainability of a photosynthetic bioreactor approach. Energy Convers Manag 46:403-420

56. Beecy D, Kuuskraa V (2001) Status of U.S. geologic carbon sequestration research and technology. Environ Geosci $8(3): 152-159$ 
57. Soong Y, Hedges SW, Howard BH, Dilmore RM, Allen DE (2014) Effect of contaminants from flue gas on $\mathrm{CO}_{2}$ sequestration in saline formation. Int J Energy Res 38:1224-1232. https://doi. org/10.1002/er.3140

58. Fang Y, Baojun B, Dazhen T, Dunn-Norman S, Wronkiewicz D (2010) Characteristics of $\mathrm{CO}_{2}$ sequestration in saline aquifers. Pet Sci 7:83-92. https://doi.org/10.1007/s12182-010-0010-3

59. Hurter S, Labregere D, Berge J (2007) Simulations for $\mathrm{CO}_{2}$ injection projects with compositional simulator. Paper SPE 108540 presented at Offshore Europe, Aberdeen, Scotland, UK

60. Coninck H, Benson SM (2014) Carbon dioxide capture and storage: issues and prospects. Annu Rev Environ Resour 39:243-270. https://doi.org/10.1146/annurev-environ-032112-095222

61. Holloway $S$ (2007) Carbon dioxide capture and geologic storage. Trans R Soc A 365:1095-1107

62. Degen J, Uebele A, Retze A, Schmid-Steger U, Trosch W (2001) A novel airlift photo bioreactor with baffles for improved light utilization through the flashing light effect. J Biotechnol 92:89-94

63. Kim J, Miller JE, Maravelias CT, Stechel EB (2013) Comparative analysis of environmental impact of S2P (Sunshine to Petrol) system for transportation fuel production. Appl Energy 111:10891098. https://doi.org/10.1016/j.apenergy.2013.06.035

64. Boretti A (2013) Renewable hydrogen to recycle $\mathrm{CO}_{2}$ to methanol. Int J Hydrog Energy 38:1806-1812. https://doi. org/10.1016/j.ijhydene.2012.11.097

65. Najafabadi AT (2013) $\mathrm{CO}_{2}$ chemical conversion to useful products: an engineering insight to the latest advances toward sustainability. Int J Energy Res 37:485-499. https://doi.org/10.1002/ er.3021

66. Izgec O, Demiral B, Bertin $\mathrm{H}$, Akin S (2008) $\mathrm{CO}_{2}$ injection into saline carbonate aquifer formations II: comparison of numerical simulations to experiments. Transp Porous Med 73:57-74. https ://doi.org/10.1007/s11242-007-9160-1

67. Rutqvist J, Tsang CF (2002) A study of caprock hydromechanical changes associated with $\mathrm{CO}_{2}$-injection into a brine formation. Environ Geol 42:296-305. https://doi.org/10.1007/s0025 4-001-0499-2

68. Mathias SA, Hardisty PE, Trudell MR, Zimmerman RW (2009) Approximate solutions for pressure buildup during $\mathrm{CO}_{2}$ injection in brine aquifers. Transp Porous Med 79:265-284. https:// doi.org/10.1007/s11242-008-9316-7

69. Taylor GI (1953) Dispersion of solute matter in solvent flowing slowly through a tube. Proc R Soc Lond Math Phys Sci 219:186203. https://doi.org/10.1098/rspa.1953.0139

70. Aris $R$ (1956) On the dispersion of a solute in a fluid flowing through a tube. Proc R Soc Lond Math Phys Sci 235(1200):67-77

71. Brenner H (1980) Dispersion resulting from flow through spatially periodic porous media. Philos Trans R Soc Lond A Math Phys Sci 297(1430):81-133

72. Brenner H, Edwards DA (1993) Macro transport processes. Butterworth-Heinemann, Oxford

73. Hongjun Z, Xinwei Liao, Yanfang Chen, Xiaoliang Zhao (2010) Sensitivity analysis of $\mathrm{CO}_{2}$ sequestration in saline aquifers. Pet Sci 7:372-378. https://doi.org/10.1007/s12182-010-0080-2

74. Beni AN, Kühn M, Meyer R, Clauser C (2012) Numerical modeling of a potential geological $\mathrm{CO}_{2}$ sequestration site at Minden (Germany). Environ Model Assess 17:337-351. https://doi. org/10.1007/s10666-011-9295-x

75. Xu T, Pruess K (1998) Coupled modeling of non-isothermal multiphase flow, solute transport and reactive chemistry in porous and fractured media: 1 . Model development and validation. Lawrence Berkeley National Laboratory Report LBNL-42050

76. Xu T, Pruess K (2001) Modeling multiphase non isothermal fluid flow and reactive geochemical transport invariably saturated fractured rocks: methodology. Am J Sci 301:16-33
77. Lee $\mathrm{U}$, Mitsos A, Han C (2016) Optimal retrofit of a $\mathrm{CO}_{2}$ capture pilot plant using superstructure and rate-based models. Int J Greenhouse Gas Control 50:57-69. https://doi.org/10.1016/j. ijggc.2016.03.024

78. Ranjith PG, Perera MSA, Khan E (2013) A study of safe $\mathrm{CO}_{2}$ storage capacity in saline aquifers: a numerical study. Int J Energy Res 2013(37):189-199

79. Azin R, Raad SMJ, Osfouri S, Fatehi R (2013) Onset of instability in $\mathrm{CO}_{2}$ sequestration into saline aquifer: scaling relationship and the effect of perturbed boundary. Heat Mass Transfer 49:16031612. https://doi.org/10.1007/s00231-013-1199-7

80. Kuramochi T, Ramírez A, Turkenburg W, Faaij A (2012) Comparative assessment of $\mathrm{CO}_{2}$ captures technologies for carbon-intensive industrial processes. Prog Energy Combust Sci 38:87-112. https://doi.org/10.1016/j.pecs.2011.05.001

81. Lorenzo GD, Barbera P, Ruggieri G, Witton J, Pilidis P, Probert D (2013) Pre-combustion carbon-capture technologies for power generation: an engineering-economic assessment. Int J Energy Res 37:389-402. https://doi.org/10.1002/er.3029

82. Craig MT, Jaramillo P, Zhai H, Klima K (2017) The economic merits of flexible carbon capture and sequestration as a compliance strategy with the clean power plan. Environ Sci Technol 51(3):1102-1109

83. Koornneef J, Ramírez A, Turkenburg W, Faaij A (2012) The environmental impact and risk assessment of $\mathrm{CO}_{2}$ capture, transport and storage-an evaluation of the knowledge base. Prog Energy Combust Sci 38:62-86. https://doi.org/10.1016/j. pecs.2011.05.002

84. Anandarajah G, McDowall W, Ekins P (2017) Decarbonising road transport with hydrogen and electricity: long term global technology learning scenarios. Int J Hydrog Energy 38:3419-3432

85. Castle JW, Wagner JR, Rodgers Jr JH, Hill GR (2011) Water in carbon capture and sequestration: challenges and opportunities. In: 28th annual international pittsburgh coal conference 2011, PCC 2011, 3, pp 1681-1692

86. https://www.carbonbrief.org/around-the-world-in-22-carbo n-capture-projects. Accessed on 2 March 2018

87. http://www.globalccsinstitute.com/projects/pilot-and-demon stration-projects. Accessed on 4 March 2018

88. http://www.eaton.com/Eaton/OurCompany/SuccessStories/ Energy/SkyonicCorporation/index.htm. Accessed 14 March 2018

89. http://sequestration.mit.edu/tools/projects/kemper.html. Accessed on 14 March 2018

90. Newmark RL, Friedmann SJ, Carroll SA (2010) Water challenges for geologic carbon capture and sequestration. Environ Manag 45(4):651-661

91. Deng H, Bielicki JM, Oppenheimer M, Fitts JP, Peters CA (2017) Leakage risks of geologic $\mathrm{CO}_{2}$ storage and the impacts on the global energy system and climate change mitigation. Clim Change 144:151-163

92. Selvadurai APS (2012) Fluid leakage through fractures in an impervious caprock embedded between two geologic aquifers. Adv Water Resour 41:76-83

93. Song J, Zhang D (2013) Comprehensive review of caprock-sealing mechanisms for geologic carbon sequestration. Environ Sci Technol 47(1):9-22

Publisher's Note Springer Nature remains neutral with regard to jurisdictional claims in published maps and institutional affiliations. 